\title{
TREM2/DAP12 Signal Elicits Proinflammatory Response in Microglia and Exacerbates Neuropathic Pain
}

\author{
Masaaki Kobayashi, ${ }^{1}$ Hiroyuki Konishi, ${ }^{1,2}$ Akira Sayo, ${ }^{1,3}$ ๑Toshiyuki Takai, ${ }^{4}$ and $\oplus^{\oplus H i r o s h i ~ K i y a m a ~}{ }^{1,2}$ \\ ${ }^{1}$ Department of Functional Anatomy and Neuroscience, Nagoya University Graduate School of Medicine, Nagoya 466-8550, Japan, ${ }^{2}$ Core Research for \\ Evolutional Science and Technology of the Japan Science and Technology Agency, Nagoya University Graduate School of Medicine, Nagoya 466-8550, \\ Japan, ${ }^{3}$ Department of Oral and Maxillofacial Surgery, Nagoya University Graduate School of Medicine, Nagoya 466-8550, Japan, and ${ }^{4}$ Department of \\ Experimental Immunology, Institute of Development, Aging and Cancer, Tohoku University, Sendai 980-8575, Japan
}

Neuropathic pain afflicts millions of people, and the development of an effective treatment for this intractable pain is an urgent issue. Recent evidence has implicated microglia in neuropathic pain. The present study showed that the DNAX-activating protein of $12 \mathrm{kDa}$ (DAP12) and its associated "triggering receptor expressed on myeloid cells 2" (TREM2) were predominantly expressed by microglia in the dorsal horn after spinal nerve injury, revealing a role for TREM2/DAP12 signaling in neuropathic pain. Nerve injury-induced proinflammatory cytokine expression in microglia and pain behaviors were significantly suppressed in Dap12-deficient mice. Furthermore, intrathecal administration of TREM2 agonistic antibody induced proinflammatory cytokine expression, as well as neuropathic pain, in mice without nerve injury. The agonistic antibody induced proinflammatory responses and neuropathic pain was not observed in Dap12-deficient mice. Together, these results suggest that TREM2/DAP12-mediated signals in microglia exacerbate nerve injuryinduced neuropathic pain by inducing proinflammatory cytokine secretion from microglia. Suppression of DAP12-mediated signals could be a therapeutic target for neuropathic pain.

Key words: dap12; microglia; pain; trem2

\section{Significance Statement}

Recent studies have revealed that activated microglia in the spinal dorsal horn exacerbate neuropathic pain, which has suggested that suppression of microglial activity should be considered as a therapeutic target. However, only a few molecules have been identified as regulators of microglial activity. In this study, we focused on a receptor complex of TREM2 and DAP12, both of which are expressed by microglia and have been implicated in the pathogenesis of Alzheimer's disease, and demonstrated that TREM2/ DAP12 signaling promoted proinflammatory responses in microglia and exacerbates neuropathic pain. The present results revealed the functional significance of TREM2/DAP12 signaling in microglial activation after neuronal injury, and could help in the development of treatments for neuropathic pain and neurodegenerative diseases.

\section{Introduction}

Neuropathic pain is a chronic and pathological pain that is induced by nerve injury, often due to metabolic, cancerous, infec-

Received April 14, 2016; revised Aug. 30, 2016; accepted Sept. 12, 2016.

Author contributions: H. Konishi and H. Kiyama designed research; M.K., H. Konishi, and A.S. performed research; T.T. contributed unpublished reagents/analytic tools; M.K., H. Konishi, and H. Kiyama analyzed data; M.K., H. Konishi, and H. Kiyama wrote the paper.

This work was supported in part by Ministry of Education, Culture, Sports, Science and Technology of Japan KAKENHI Grants-in-Aid for Scientific Research on Priority Areas Brain Environment to H. Kiyama and Grants-in-Aid for Young Scientist (B) to H. Konishi, Core Research for Evolutional Science and Technology of Japan Science and Technology Agency to H. Kiyama, and the Hibino Foundation, the Ichiro Kanehara Foundation, and the Hori Sciences and Arts Foundation to H. Konishi. Fluorescent microscope BZ-9000 and flow cytometer Canto II were used in the Laboratory of Division for Medical Research Engineering, Nagoya University Graduate School of Medicine. We thank Dr. Mary Humphrey (University of Oklahoma Health Sciences Center) for providing anti-pDAP12 antibody, Drs. Okiru Komine and Koji Yamanaka (Nagoya University Research Institute of Environmental Medicine) for advising flow tious, chemical, or traumatic impairments (Grace et al., 2014). Allodynia, a significant sensory aberration elicited by a nonnoxious stimulus, and hyperalgesia, an increased pain response to a noxious stimulus, are some of the major symptoms (Woolf and Mannion, 1999). Much work has been done to establish effective treatments for neuropathic pain, and several molecular mechanisms underlying neuropathic pain have been revealed. However, the more precise and integrative molecular and cellular

cytometry, Naomi Tawarayama, Noriko Usami, Yoshiko Itai, and Miyoko Okamoto for their technical assistance, and Ayako Asano for secretarial work.

The authors declare no competing financial interests.

Correspondence should be addressed to Dr. Hiroshi Kiyama, Department of Functional Anatomy and Neuroscience, 65, Tsurumai-cho, Showa-ku, Nagoya 466-8550, Japan. E-mail: kiyama@med.nagoya-u.ac.jp.

DOI:10.1523/JNEUROSCI.1238-16.2016

Copyright $\odot 2016$ the authors $\quad 0270-6474 / 16 / 3611138-13 \$ 15.00 / 0$ 
mechanisms remain poorly understood, and to date there are no established successful or practical treatments. Recently, microglia have emerged as key players in eliciting neuropathic pain in the spinal cord (Inoue and Tsuda, 2009; Maeda et al., 2010; Tsuda et al., 2013; Grace et al., 2014; Yasui et al., 2014). Microglia, which are the immunocompetent cells in the CNS, are able to quickly respond to injury and infection, and play a pivotal role in the scavenging of pathogens and maintaining tissue homeostasis. However, when microglia are exposed to abnormal conditions, such as severe traumatic injury or inflammation in the CNS, they change their functional phenotype and secrete an excess of proinflammatory cytokines and reactive oxygen species. This further results in neuronal damage. Nerve injury readily induces this adverse environment and has been shown to play a role in neuropathic pain (Leung and Cahill, 2010; Yasui et al., 2014).

DNAX-activating protein of $12 \mathrm{kDa}$ (DAP12) (also known as TYRO protein kinase-binding protein [TYROBP] and killer cell activating receptor-associated protein [KARAP]) is a single-pass transmembrane adaptor protein that is mainly expressed in various myeloid cells and natural killer cells (Lanier, 2009). Previous reports from our group and others have demonstrated that DAP12 is predominantly expressed in microglia in the CNS and in macrophage in the periphery (Roumier et al., 2004; Thrash et al., 2009; Kobayashi et al., 2015). DAP12 contains an immunoreceptor tyrosine-based activation motif (ITAM) in the cytoplasm and does not have ligand-binding capabilities because of its short extracellular domain, resulting in the formation of complexes with specific partner membrane receptors (Lanier, 2009). Once the ligand binds to the DAP12-associated receptors, DAP12 sends signals through the ITAM within its cytoplasmic domain and induces cellular activation (Tomasello et al., 1998; Takaki et al., 2006), such as cytokine production, proliferation, and survival of macrophages (Turnbull et al., 2005; Otero et al., 2009), osteoclast differentiation (Kaifu et al., 2003), and antigen presentation, maturation, and survival of dendritic cells (Bouchon et al., 2001). In the CNS, DAP12 and the triggering receptor expressed on myeloid cells 2 protein (TREM2), a DAP12-associated receptor expressed by myeloid cells and microglia, have been implicated in the pathogenesis of Alzheimer's disease (Guerreiro et al., 2013; Jonsson et al., 2013; Zhang et al., 2013). A Trem2 mutation has been shown to confer a risk of late-onset Alzheimer's disease (Guerreiro et al., 2013; Jonsson et al., 2013), and Dap12 mutations in humans results in Nasu-Hakola disease, which is characterized by progressive presenile dementia and bone cysts (Paloneva et al., 2000).

We recently reported that DAP12-mediated signals promote inflammatory polarization in microglia following motor nerve injury, and microglial DAP12-mediated signals exacerbate degeneration of injured motor neurons (Kobayashi et al., 2015). More recently, injured sensory neuron-derived colonystimulating factor 1 (CSF1) was shown to be a critical inducer of microglia-mediated pain, with signaling via the CSF1 receptor (CSF1R) and DAP12 on microglia (Guan et al., 2016). Although this report demonstrated the significance of CSF1R/ DAP12 signaling in microglial stimulation, several DAP12associated receptors are expressed by microglia. Therefore, the present study addressed the crucial role that DAP12 plays in the microglial phenotype leading to neuropathic pain, and provided evidence that additional pathways, such as the TREM2/DAP12-mediated pathway, is also critical for determining the microglial phenotype and initiating neuropathic pain.
Table 1. Primers used for qRT-PCR

\begin{tabular}{|c|c|c|c|}
\hline Gene & Accession number & Primer s & quence $\left(5^{\prime}-3^{\prime}\right)$ \\
\hline DAP12 & ВС056450 & $\begin{array}{l}\text { Forward } \\
\text { Reverse }\end{array}$ & $\begin{array}{l}\text { gattgecctggctgtgtact } \\
\text { ctggtctctgaccctgaagc }\end{array}$ \\
\hline TREM2 & BC052784 & $\begin{array}{l}\text { Forward } \\
\text { Reverse }\end{array}$ & $\begin{array}{l}\text { ggaaccgtcaccatcactct } \\
\text { atgctggctgcaagaaactt }\end{array}$ \\
\hline TNF- $\alpha$ & NM_013693 & $\begin{array}{l}\text { Forward } \\
\text { Reverse }\end{array}$ & $\begin{array}{l}\text { gtggaactggcagaagaggc } \\
\text { agacagaagagcgtggtggc }\end{array}$ \\
\hline IL-1 $\beta$ & NM_008361 & $\begin{array}{l}\text { Forward } \\
\text { Reverse }\end{array}$ & $\begin{array}{l}\text { ctgtgtctttcccgtggacc } \\
\text { cagctcatatgggtccgaca }\end{array}$ \\
\hline IL-6 & NM_031168 & $\begin{array}{l}\text { Forward } \\
\text { Reverse }\end{array}$ & $\begin{array}{l}\text { ttccatccagttgcttctt } \\
\text { cagaattgccattgcacaac }\end{array}$ \\
\hline IRF5 & AF028725 & $\begin{array}{l}\text { Forward } \\
\text { Reverse }\end{array}$ & $\begin{array}{l}\text { cctcagccgtacaagatctacga } \\
\text { gtagcattctctggagctcttcct }\end{array}$ \\
\hline IRF8 & NM_008320 & $\begin{array}{l}\text { Forward } \\
\text { Reverse }\end{array}$ & $\begin{array}{l}\text { gagctgcagcaattctacgc } \\
\text { aagggtctctggtgtgaggt }\end{array}$ \\
\hline Ctss & ВС002125 & $\begin{array}{l}\text { Forward } \\
\text { Reverse }\end{array}$ & $\begin{array}{l}\text { gttgggctttcagtgctgtg } \\
\text { ggataggaagcgtctgcctc }\end{array}$ \\
\hline P2RX4 & NM_011026 & $\begin{array}{l}\text { Forward } \\
\text { Reverse }\end{array}$ & $\begin{array}{l}\text { acaacgtgtctcctggctacaat } \\
\text { gtcaaacttgccagcctttcc }\end{array}$ \\
\hline BDNF & BC034862 & $\begin{array}{l}\text { Forward } \\
\text { Reverse }\end{array}$ & $\begin{array}{l}\text { tacctggatgccgcaaacat } \\
\text { agttggectttggataccgg }\end{array}$ \\
\hline
\end{tabular}

\section{Materials and Methods}

Animals. All animal experiments were conducted in accordance with the standard guidelines of the Nagoya University Graduate Schools of Medicine. The male mice used in this study were $10-15$ weeks of age at the start of each experiment. Wild-type (WT) C57BL/6 mice were purchased from Charles River Laboratories Japan. Dap12-deficient $\left(\right.$ Dap $12^{-/-}$or Tyrobp $\left.{ }^{-1-}\right)$ mice were backcrossed into the C57BL/6 genetic background for at least 12 generations (Kaifu et al., 2003). C-C chemokine receptor type 2 (Ccr2) ${ }^{\mathrm{RFP} / \mathrm{RFP}}$ mice were obtained from The Jackson Laboratory. All mice were housed at a controlled temperature $\left(23 \pm 1^{\circ} \mathrm{C}\right)$ with a $12 \mathrm{~h}$ light-dark cycle (light on 9:00 to 21:00), and acclimated to the environment for $>1$ week before the experiments in accordance with the Guide for the care and use of laboratory animals. The study was conducted with the approval of the local animal ethics committee in accordance with the regulations for animal experiments at Nagoya University (permission 24294, 25107, 26181, 27204, and 28303), the Animal Protection and Management Law of Japan (105), and the Ethical Issues of the International Association for the Study of Pain (Zimmermann, 1983).

Surgical procedure of the neuropathic pain model. To generate neuropathic pain in mice, we used the L4 spinal nerve injury model with some modifications (Kim and Chung, 1992; Tsuda et al., 2003; Masuda et al., 2012, 2014). Under 3\% isoflurane anesthesia, mice were put in a prone position. A small incision at L3-S1 was made on the left side. The paraspinal muscles were cut and partially removed from the L5 transverse process. We preserved the L 5 transverse process without removing it. To expose the L4 spinal nerve, trimming around the intervertebral foramen was performed. Then, the left L4 nerve was carefully dissociated and cut. The muscle layer of the wound and skin were tightly sutured with 6-0 silk.

$q R T-P C R$. We harvested the L4 spinal cords from 4 mice from each group. The spinal cords were then vertically separated along the median. Hemisections of the ipsilateral and contralateral side were horizontally divided into dorsal horn $(\mathrm{DH})$ and ventral horn according to the bottom line of the substantia gelatinosa under the microscope. DH tissues were subjected to total RNA extraction using the acid guanidine isothiocyanate/phenol/chloroform extraction method. Total RNA was quantified using a Nanodrop spectrophotometer (Thermo Scientific). cDNA was prepared from total RNA by reverse transcription reaction with SuperScript III (Invitrogen). qRT-PCR was performed with StepOnePlus (Applied Biosystems) using Fast SYBR Green Master Mix (Applied Biosystems). Primers are described in Table 1. The conditions for fast qRT-PCR were as follows: 1 cycle of $95^{\circ} \mathrm{C}$ for $20 \mathrm{~s}, 40$ cycles of $95^{\circ} \mathrm{C}$ for $3 \mathrm{~s}$, and $60^{\circ} \mathrm{C}$ for $30 \mathrm{~s}$. At the end of the PCR, the samples were subjected to a melting analysis to confirm amplicon specificity. Results were normal- 
ized to glyceraldehyde-3-phosphate dehydrogenase (Gapdh). Fold changes in gene expression were calculated using the $2^{-\Delta \mathrm{Ct}}$ method.

In situ hybridization. cDNA fragments (Dap12: 72-352 of accession number BC056450; Trem2: 93-1038 of accession number BC052784) were inserted into a pGEM-T easy vector (Promega). cRNA probes were synthesized in vitro using T7 RNA polymerase (Promega) and digoxigenin (DIG) RNA Labeling Mix (Roche Applied Science). In situ hybridization was performed as previously described (Braissant and Wahli, 1998; Nakadate et al., 2009). In brief, 10- $\mu$ m-thick fresh frozen sections of the spinal cord were prepared using a cryostat CM1850 (Leica Biosystems), followed by fixation in 4\% PFA, and were washed twice in PBScontaining $0.1 \%$ active diethylpyrocarbonate. After equilibration in hybridization buffer (50\% formamide, $5 \times$ SSC, $40 \mu \mathrm{g} / \mathrm{ml}$ salmon sperm DNA), sections were hybridized with DIG-labeled riboprobe in hybridization buffer for $18 \mathrm{~h}$ at $58^{\circ} \mathrm{C}$. After washing, DIG was visualized following incubation with alkaline phosphatase-conjugated anti-DIG Fab fragment (1:2000; Roche Applied Science) for $2 \mathrm{~h}$ and NBT/BCIP (1:50; Roche Applied Science) for $15 \mathrm{~h}$ at room temperature. For doublelabeling with immunohistochemistry, the sections were first processed for in situ hybridization and then immunohistochemistry was performed. The images were taken with a BZ-9000 microscope (Keyence).

Immunohistochemistry. Immunohistochemistry was performed as previously described (Konishi et al., 2006; Kobayashi et al., 2015). Mice were deeply anesthetized with an intraperitoneal injection of sodium pentobarbital and transcardially perfused with normal saline followed by Zamboni's fixative ( $0.1 \mathrm{M}$ PB-containing $2 \%$ PFA and $0.2 \%$ picric acid). The L4 spinal cords were removed from perfused mice and were postfixed in the same fixative for $15-18 \mathrm{~h}$ at $4^{\circ} \mathrm{C}$. The tissues were then immersed in $20 \%$ sucrose in $0.1 \mathrm{M} \mathrm{PB}$ at $4^{\circ} \mathrm{C}$ overnight. Then, the $14-\mu \mathrm{m}-$ thick sections of the L4 spinal cord were cut and reacted with primary antibodies for $4 \mathrm{~h}$ at room temperature or overnight at $4^{\circ} \mathrm{C}$. Primary antibodies were as follows: anti-interferon regulatory factor 8 (IRF8) (\#sc-6058, Santa Cruz Biotechnology; 1:250), anti-ionized calciumbinding adaptor molecule 1 (Iba1) (\#ab5076, Abcam; 1:500), antiDAP12 (\#AB4070, Millipore; 1:250), anti-phosphorylated DAP12 (pDAP12) (a generous gift from Dr. Humphrey at University of Oklahoma Health Sciences Center) (1:250) (Peng et al., 2010), and antiprotein kinase C gamma (PKC $\gamma$ ) (\#sc-211, Santa Cruz Biotechnology; 1:500). Signals were visualized with Alexa-488 or -594-conjugated secondary antibodies (Invitrogen). Microglial nuclei were stained with DAPI $(500 \mathrm{ng} / \mathrm{ml}$; Dojindo Laboratories) for quantifying microglial numbers. Images were taken with a confocal microscope (FV10i, Olympus) or fluorescent microscope BZ-9000.

Histological analysis. To quantify Iba1-positive cell number and area, triple immunofluorescence was performed using anti-Ibal antibody, anti-PKC $\gamma$ antibody (to identify the inner lamina II), and DAPI. The same laser power and sensitivities of confocal microscope (FV10i) were used to analyze the randomly chosen $14-\mu \mathrm{m}$-thick sections, and the areas of lamina I and II were defined and calculated. Iba1-positive cells that contained distinct DAPI signals were counted and normalized to the area. Iba1-positive areas were also measured after background correction by FV10-ASW software (Olympus) and normalized to the area. A total of 12 sections taken from 3 animals were examined for each time point. In these experiments, the interval of each section was at least $112 \mu \mathrm{m}$, and there was no possibility of repetitive counting of the same cells.

Behavioral testing. The mechanical withdrawal threshold was measured using 0.02-0.2 g von Frey filaments (Touch Test Sensory Evaluator) to evaluate mechanical sensitivity. Mice were individually placed on the wire mesh floor, covered by an opaque chamber, and habituated for at least $30 \mathrm{~min}$ before testing to acclimate to their new environment. Subsequently, von Frey filaments were applied to the plantar surfaces of their hindpaws. The 50\% paw withdrawal threshold (PWT) was determined using the up-down method (Chaplan et al., 1994).

Flow cytometry. Microglia were isolated from $\mathrm{DH}$ according to a previous report with some modifications (Singh et al., 2014). Briefly, one WT and one Dap12-deficient mouse $3 \mathrm{~d}$ after L4 spinal nerve transection were perfused with PBS, and a $5 \mathrm{~mm}$ segment around L4 DH was dissected. The $\mathrm{DH}$ tissue was minced by blades, treated with $20 \mathrm{U} / \mathrm{ml}$ papain (Roche Applied Science) and $10 \mu \mathrm{g} / \mathrm{ml}$ DNase I (Roche Applied Science),
Table 2. Primers used for conventional PCR

\begin{tabular}{|c|c|c|c|}
\hline Gene & Accession number & Primer se & juence $\left(5^{\prime}-3^{\prime}\right)$ \\
\hline DAP12 & BC056450 & $\begin{array}{l}\text { Forward } \\
\text { Reverse }\end{array}$ & $\begin{array}{l}\text { ctggtgccttctgttccttc } \\
\text { ctggtctctgaccctgaagc }\end{array}$ \\
\hline TREM2 & BC052784 & $\begin{array}{l}\text { Forward } \\
\text { Reverse }\end{array}$ & $\begin{array}{l}\text { ctgcacttcaagggaaaagc } \\
\text { agagtgatggtgacggttcc }\end{array}$ \\
\hline TREM1 & BC111875 & $\begin{array}{l}\text { Forward } \\
\text { Reverse }\end{array}$ & $\begin{array}{l}\text { acctcccactcaccttcctt } \\
\text { atacgtggttcagccactcc }\end{array}$ \\
\hline TREM3 & BC127036 & $\begin{array}{l}\text { Forward } \\
\text { Reverse }\end{array}$ & $\begin{array}{l}\text { ccaagctggagatgaggaag } \\
\text { cccagctttgcagagaaaga }\end{array}$ \\
\hline SIRP- $\beta$ & AB109404 & $\begin{array}{l}\text { Forward } \\
\text { Reverse }\end{array}$ & $\begin{array}{l}\text { tcacgctgaagtggttcaag } \\
\text { tctgcttgtccatcatgctc }\end{array}$ \\
\hline MDL-1 & BC104364 & $\begin{array}{l}\text { Forward } \\
\text { Reverse }\end{array}$ & $\begin{array}{l}\text { gactgaaaccageccaggaa } \\
\text { cttttccectecttcccac }\end{array}$ \\
\hline CD300C & NM_199225 & $\begin{array}{l}\text { Forward } \\
\text { Reverse }\end{array}$ & $\begin{array}{l}\text { actgtgggggagtcactcag } \\
\text { gaccacgaacacctcaacct }\end{array}$ \\
\hline CD300D & NM_134158 & $\begin{array}{l}\text { Forward } \\
\text { Reverse }\end{array}$ & $\begin{array}{l}\text { ttcgagccttgagagtggtag } \\
\text { gctcaggaacaggaacaacttc }\end{array}$ \\
\hline CD300E & BC034097 & $\begin{array}{l}\text { Forward } \\
\text { Reverse }\end{array}$ & $\begin{array}{l}\text { catgtccctcacacacttgg } \\
\text { ctgaaacgggcatagttggt }\end{array}$ \\
\hline CD200R3 & BC106838 & $\begin{array}{l}\text { Forward } \\
\text { Reverse }\end{array}$ & $\begin{array}{l}\text { ctggecttcctgcagactac } \\
\text { ccaggagctttgcctaattg }\end{array}$ \\
\hline CD200R4 & BC131972 & $\begin{array}{l}\text { Forward } \\
\text { Reverse }\end{array}$ & $\begin{array}{l}\text { tccagcatgaggggacttac } \\
\text { ggacaggtaagctggattgc }\end{array}$ \\
\hline CSF1R & NM_001037859 & $\begin{array}{l}\text { Forward } \\
\text { Reverse }\end{array}$ & $\begin{array}{l}\text { ctgcgatgtgtgagcaa } \\
\text { cttgcggataatgaaccct }\end{array}$ \\
\hline
\end{tabular}

and then dispersed by pipetting. Cells were filtrated with $70 \mu \mathrm{m}$ cell strainer (Corning), resuspended in $37 \%$ Percoll (GE Healthcare) in PBS and centrifuged at $500 \times g$ for $20 \mathrm{~min}$ at $25^{\circ} \mathrm{C}$ to enrich microglia. After washing the pellet with PBS-containing $0.5 \%$ BSA, Fc receptors were blocked with anti-CD16/CD32 antibodies (eBioscience) and then cells were stained with anti-CD11b-APC (Biolegend) and anti-CD45-Pacific Blue (Biolegend). Finally total cells obtained from one animal were resuspended in $500 \mu \mathrm{l}$ of PBS containing 0.5\% BSA with 1000 latex fluorescent beads (Flow-Count, Beckman Coulter Life Sciences) to quantify cell numbers. Flow cytometry was performed by Canto II (BD Biosciences), and data were analyzed by FlowJo software (Tree Star). A total of 5000 events were recorded, and the number of $\mathrm{CD} 11 \mathrm{~b}^{+} / \mathrm{CD} 45^{\text {low }} \mathrm{mi}-$ croglia was normalized to that of beads. The ratio (Dap $\left.12^{-/-} / \mathrm{WT}\right)$ of five independent experiments was statistically analyzed.

Conventional RT-PCR. In addition to DH cDNA, cDNA was prepared from positive control tissues, such as spleen. Primers are described in Table 2. The conditions for PCRs were as follows: 1 cycle of $94^{\circ} \mathrm{C}$ for $30 \mathrm{~s}, 30-35$ cycles of $55^{\circ} \mathrm{C}-60^{\circ} \mathrm{C}$ for $30 \mathrm{~s}$, and $72^{\circ} \mathrm{C}$ for $30 \mathrm{~s}$. The amplified products were loaded on an agarose gel and stained with ethidium bromide.

Intrathecal administration of antibodies. Mice were intraperitoneally injected with $50 \mu \mathrm{g}$ Gentacin (gentamicin sulfate, Merck Sharp \& Dohme) before surgery. Under 3\% isoflurane anesthesia, the mice were placed in a prone position, and an incision was made on the back. The paraspinal muscles and ligaments were partially cut, and the L5 spinous process was removed. A 32-guage catheter (ReCathCo) was intrathecally inserted to a length of $14 \mathrm{~mm}$ through a dural incision made by a 22 guage needle. Mice, whose hindlimb muscle contracted during catheter insertion, were eliminated to exclude the possibility that catheter insertion could affect hindlimb behavior or DH gene expression. The distal side of the catheter remained outside of the skin, and muscles and skin were tightly sutured with 6-0 silk. A total of $5 \mu \mathrm{g}$ Gentacin was injected via catheter at the end of surgery. The next day, mice with abnormal behaviors, such as paralysis, were eliminated. Mice with paralyzed limbs after intrathecal injection of $2 \mu \mathrm{l} 2 \%$ xylocaine (Astra Zeneca) were selected and used for the study. After an interval of $1 \mathrm{~d}$, a total of $1 \mu \mathrm{g}$ anti-TREM2 antibody (\#MCA4772, AbD Serotec) or isotype control antibody (Rat IgG1, \#12-4031, eBioscience) was intrathecally injected once a day for $3 \mathrm{~d}$. A total of $5 \mu \mathrm{l}$ saline was then injected to flush after each antibody injection. Behavioral testing ( $n=7$ or 8$)$ and DH sampling $(n=4)$ were performed at $2 \mathrm{~h}$ after final administration. 

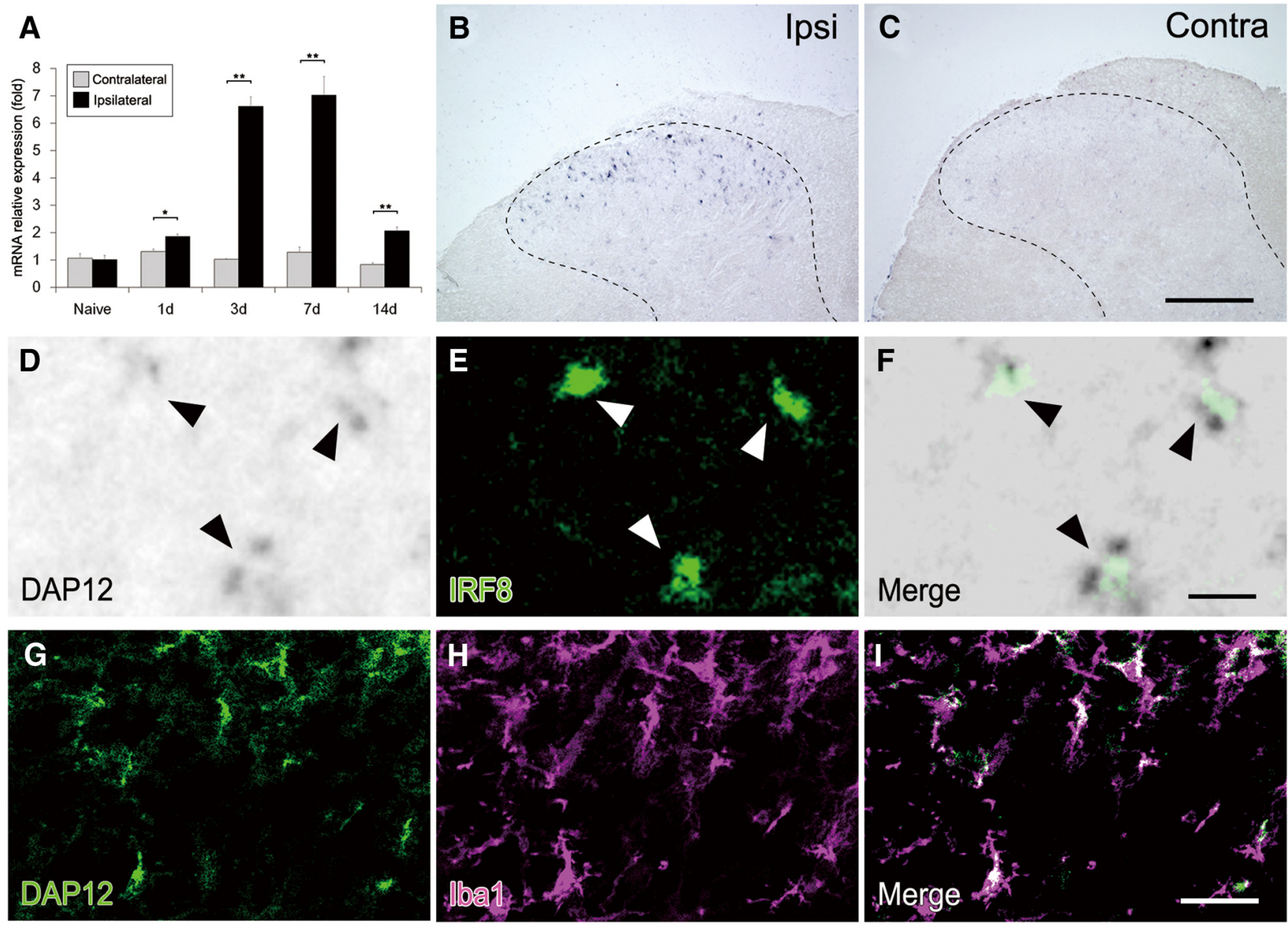

Figure 1. DAP12 expression is induced in microglia after L4 nerve injury. A, qRT-PCR analysis of Dap $12 \mathrm{mRNA}$ extracted from ipsilateral and contralateral $L 4 D H$ of WT mice before (Naive) and after L4 nerve injury. Results are normalized to the housekeeping gene Gapdh ( $n=4$ for each time point). Values are mean \pm SEM. ${ }^{*} p<0.05$ (two-way ANOVA with posthoc Turkey's test). ${ }^{* *} p<0.001$ (two-way ANOVA with post hoc Turkey's test). B, C, In situ hybridization shows increased Dap 12 mRNA expression in the spinal DH $7 \mathrm{~d}$ after L4 nerve injury (low-magnification images). $\boldsymbol{B}$, Ipsi, Ipsilateral side. C, Contra, Contralateral side. Scale bar, $200 \mu \mathrm{m}$. D-F, Localization of Dap12 mRNA in microglia in ipsilateral DH (high-magnification images). Hybridized cells (D) have IRF8 immunoreactivity (E) in their nuclei (arrowheads). Scale bar, $10 \mu \mathrm{m}$. G-I, Colocalization of DAP12 (G, green) and lba1 (H, magenta) protein in L4 DH $7 \mathrm{~d}$ after L4 nerve injury. Scale bar, $20 \mu \mathrm{m}$.

Statistical analysis. Values are mean \pm SEM. Flow cytometry data were analyzed by paired Student's $t$ test. Other data were analyzed by one- or two-way ANOVA with post hoc Turkey's test. $p<0.05$ was considered statistically significant.

\section{Results}

Induction of DAP12 microglial expression in the dorsal horn (DH) following nerve injury

To analyze the involvement of DAP12-mediated signals in neuropathic pain, we used the modified Chung model (Kim and Chung, 1992), which was previously demonstrated to cause reproducible mechanical allodynia and has been used in mice (Tsuda et al., 2003; Masuda et al., 2012; Masuda et al., 2014).

We transected the mouse L4 spinal nerve and performed qRTPCR analysis using spinal DH tissues at the L4 level after nerve injury to measure Dap12 mRNA expression changes. Dap12 mRNA significantly increased in the ipsilateral DH from $1 \mathrm{~d}$ after nerve injury ( $p=0.041$, two-way ANOVA with post hoc Turkey's test), with a peak at $7 \mathrm{~d}\left(p=1.9 \times 10^{-15}\right.$, two-way ANOVA with post hoc Turkey's test) (Fig. $1 A$ ).

To identify cell types that express Dap12 mRNA in the DH after nerve injury, double-labeling of in situ hybridization and immunohistochemistry was conducted. Previous results have shown that Dap12 mRNA is expressed by microglia (Kobayashi et al., 2015). Therefore, anti-IRF8 antibody, which specifically labels microglial nuclei in the CNS (Masuda et al., 2012), was used. The hybridized sections were stained with anti-IRF8 antibody following visualization of Dap12 mRNA by in situ hybridization. Consistent with qRT-PCR results, there was a significant increase in Dap12 mRNA-positive cells in the ipsilateral DH (Fig. $1 B, C$ ). Most mRNA staining colocalized with IRF8-positive immunostaining, suggesting that Dap12-expressing cells were microglia (Fig. $1 D-F$ ). To further confirm the increased DAP12 protein in the ipsilateral side, we performed double immunostaining using antibodies against DAP12 and Iba1, a microglial marker. Results showed that most DAP12-positive cells also expressed Iba1 (Fig. $1 G-I)$, suggesting that DAP12 is predominantly expressed by microglia and induced in the $\mathrm{DH}$ after peripheral nerve injury.

\section{DAP12 phosphorylation in microglia is induced in a} neuropathic pain model

DAP12 is a transmembrane adaptor protein that does not have ligand-binding capabilities; signaling via DAP12 is transduced downstream by tyrosine phosphorylation of ITAM in the DAP12 cytoplasmic domain after ligation with DAP12-associated receptors ligand (Peng et al., 2010). To determine whether DAP12mediated signaling in microglia is activated in response to nerve 
injury, we used an antibody specific for pDAP12, the tyrosinephosphorylated form of DAP12 (Peng et al., 2010). WT mice at $7 \mathrm{~d}$ after nerve injury, robust activation of DAP12 phosphorylation was detected in Iba1-positive microglia in the ipsilateral $\mathrm{DH}$, whereas pDAP12 expression in the contralateral DH was very low (Fig. $2 A-F)$. In the Dap12-deficient $\left(D a p 12^{-1-}\right.$ ) mice (Kaifu et al., 2003), there were no pDAP12-positive cells, although an intense Iba1 signal was observed (Fig. $2 G-L$ ). This also suggests a specificity of the antibody we used in this experiment. Together, these results suggest that microglial DAP12 could be activated by DAP12-associated receptor activation in response to nerve injury.

\section{DAP12 signals augment nerve injury-induced neuropathic pain}

Microglia play crucial roles in the development and prolongation of neuropathic pain (Inoue and Tsuda, 2009; Tsuda et al., 2013). We evaluated the functional relevance of microglial DAP12 expression on mechanical allodynia, a pathognomonic symptom of neuropathic pain characterized by aberrant pain hypersensitivity initiated by innocuous stimuli (Tsuda et al., 2005). Using WT and Dap $12^{-1-}$ mice, mechanical allodynia was evaluated by measuring PWT to von Frey filament stimulation of the hindpaw after unilateral nerve injury. In the ipsilateral side of WT, there was a decrease in PWT from 3 to $42 \mathrm{~d}$ after nerve injury, whereas Dap $12^{-1-}$ mice exhibited significantly higher PWTs compared with WT mice at all time points examined (preoperation: $p=$ $0.93 ; 3 \mathrm{~d}: p=0.0017 ; 7 \mathrm{~d}: p=0.0021 ; 14 \mathrm{~d}: p=0.011 ; 28 \mathrm{~d}: p=$ $0.00019 ; 35 \mathrm{~d}: p=0.0049 ; 42 \mathrm{~d}: p=0.00015$, two-way ANOVA with post hoc Turkey's test), although Dap12 deficiency did not suppress the pain behavior completely (Fig. 3A). At $42 \mathrm{~d}$, PWT was ameliorated in Dap $12^{-1-}$ mice and similar to the preoperative state, whereas WT mice remained hypersensitive. There was no significant difference in pain behavior between WT and Dap $12^{-1-}$ contralateral sides throughout the experimental period (preoperation: $p=0.95 ; 3 \mathrm{~d}: p=0.23 ; 7 \mathrm{~d}: p=0.93 ; 14 \mathrm{~d}: p=$ $0.36 ; 28 \mathrm{~d}: p=0.87 ; 35 \mathrm{~d}: p=0.82 ; 42 \mathrm{~d}: p=0.79$, two-way ANOVA with post hoc Turkey's test) (Fig. 3B). Together, Dap $12^{-1-}$ mice exhibited suppressed mechanical allodynia and early recovery after nerve injury. These findings suggested that DAP12-mediated signals in microglia augment neuropathic pain.

\section{Dap12 deficiency reduces microglial numbers in the DH after nerve injury}

To elucidate the causative difference in pain behavior between WT and Dap $12^{-1-}$ mice in the neuropathic pain model, microglial numbers and morphology were examined using Ibal staining.

Before quantifying microglia, we examined the possibility of circulating monocyte infiltration in $C \mathrm{cr} 2^{\mathrm{RFP} /+}$ mice, which could affect pain behavior after nerve injury (Fig. 4). CCR2 promoter-derived RFP expression allows for unequivocal distinction between infiltrating monocytes/macrophages and resident microglia (Saederup et al., 2010). In the ipsilateral dorsal root, the number of RFP-positive infiltrated monocytes/macrophages increased (Fig. 4, arrowhead), although there were almost no RFPpositive cells in the contralateral dorsal root as previously reported (Siebert et al., 2000). Simultaneously, there was an increase in Iba1-positive cells in the ipsilateral DH, but few RFPpositive cells in the ipsilateral DH (Fig. 4). These results suggested that in the present neuropathic pain model, Iba1-positive cells in the $\mathrm{DH}$ were derived from proliferated and/or migrated resident microglia and not from infiltrated circulating monocytes.

Iba1-positive microglia and the area of Ibal expression were quantified in lamina I and II regions, which are critical layers of etiology in the neuropathic pain model (Fig. 5A-H). Antibodies against PKC $\gamma$ were used to visualize the layers; PKC $\gamma$ staining reveals a clear boundary of the inner lamina II in the DH (Fig. $5 B, F$ ) (Malmberg et al., 1997). There was no significant basal difference in Ibal-positive area $(p=0.81)$ and microglial numbers $(p=0.98)$ between the two genotypes of naive mice. However, after nerve injury, there were significantly smaller Iba1-positive area $\left(1 \mathrm{~d}: p=0.044 ; 3 \mathrm{~d}: p=2.0 \times 10^{-7} ; 7 \mathrm{~d}: p=\right.$ 0.0052; $14 \mathrm{~d}: p=0.017$, two-way ANOVA with post hoc Turkey's test) and less microglial cells ( $1 \mathrm{~d}: p=0.0031 ; 3 \mathrm{~d}: p=2.2 \times 10^{-8}$; $7 \mathrm{~d}: p=0.23 ; 14 \mathrm{~d}: p=0.0051$, two-way ANOVA with post hoc Turkey's test) in the Dap $12^{-1-}$ mice compared with WT mice throughout time points examined (Fig. $5 I, J$ ). The Iba1-positive area and the number of microglia of Dap $12^{-1-}$ mice decreased to $59.9 \%$ and $68.5 \%$, respectively, compared with WT mice at $3 \mathrm{~d}$ after nerve injury (Fig. $5 \mathrm{I}, \mathrm{J}$ ). To confirm the reduction of microglial numbers in Dap $12^{-1-}$ mice, we performed a flow cytometric assay at $3 \mathrm{~d}$ after nerve injury and demonstrated that microglial numbers in ipsilateral DH of Dap $12^{-1-}$ mice decreased to $65.7 \%$ $(p=0.030)$ (Fig. $5 K, L)$. These results suggested that DAP12mediated signals likely participate in microglial migration, proliferation, and/or survival after nerve injury.

\section{Dap12 deficiency suppresses proinflammatory responses in neuropathic pain model}

Representative proinflammatory cytokines, such as TNF- $\alpha$, interleukin- $1 \beta$ (IL-1 $\beta$ ), and IL-6, are involved in inflammatory and neuropathic pain (He et al., 2010; Leung and Cahill, 2010). These cytokines are mainly released by microglia in the CNS in response to a variety of stimuli, such as nerve injury. We previously reported that microglial DAP12-mediated signaling induces a proinflammatory response after motor nerve injury in vivo, as well as after LPS stimulation in vitro (Kobayashi et al., 2015), suggesting that a similar mechanism might be involved in neuropathic pain.

Tissues from the ipsilateral DH of WT and Dap $12^{-1-}$ mice after L4 spinal nerve injury were examined by qRT-PCR with respect to neuropathic pain-related molecules. From the early phase after injury, mRNA expression for Tnfa and Il6 was induced in the DH; however, the induction was significantly suppressed in the Dap12 $1-$ mice compared with WT mice (Fig. $6 \mathrm{~A}, \mathrm{C})$. Additionally, induction of $I l 1 b$, whose expression peaked at $7 \mathrm{~d}$ after injury, was also suppressed (Fig. 6B). Induction of the Irf5 and Irf 8 transcriptional factors, which are expressed by microglia in the CNS and are considered important for gene expression of proinflammatory cytokines (Takaoka et al., 2005; Krausgruber et al., 2011) and neuropathic pain (Masuda et al., 2012; Masuda et al., 2014), was also significantly suppressed in the Dap $12^{-1-}$ mice (Fig. 6D,E). Induction of cathepsin S (Ctss), which has also been shown to be involved in neuropathic pain (Clark et al., 2007), was suppressed in Dap $12^{-1-}$ mice only during the later stages after injury (Fig. $6 F$ ). The purinergic receptor $\mathrm{P} 2 \mathrm{X} 4$ (P2RX4)-BDNF axis is also considered a critical regulator of nerve injury-induced neuropathic pain (Tsuda et al., 2003; Coull et al., 2005). Although only slight statistical differences at certain time points were seen, a decreased tendency in induction of P2rx4 and Bdnf mRNAs was observed throughout the experimental period (Fig. 6G,H). These findings suggest that DAP12 plays a role in the development of neuropathic pain, partly by 

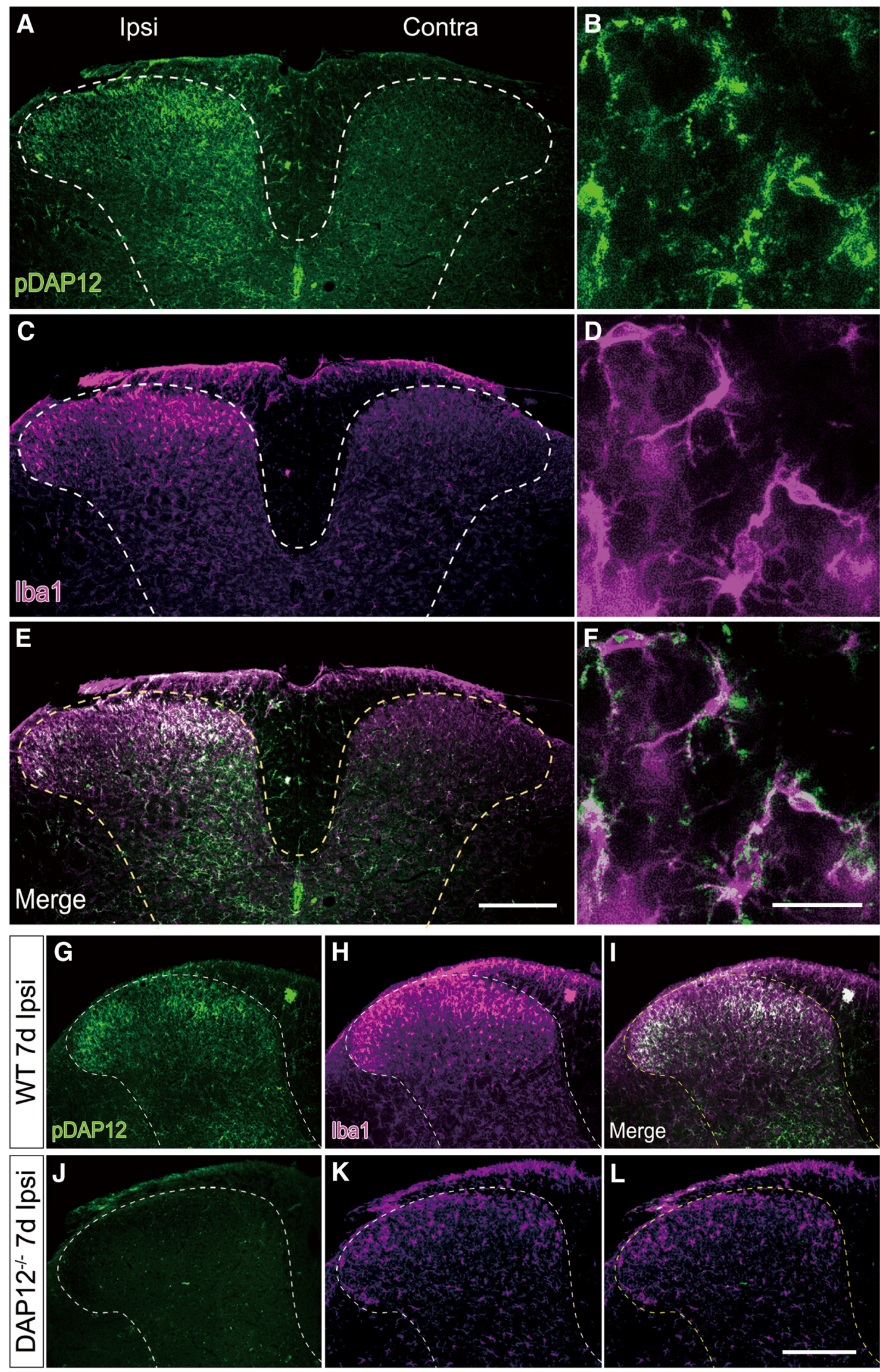

Figure 2. Microglial DAP12 is phosphorylated in neuropathic pain states. $\boldsymbol{A}-\boldsymbol{F}$, Visualization of pDAP12 ( $\boldsymbol{A}, \boldsymbol{B}$, green) and lba1 ( $\boldsymbol{C}, \boldsymbol{D}$, magenta) protein in the spinal $\mathrm{DH} 7 \mathrm{~d}$ after $\mathrm{L} 4$ nerve injury. pDAP12 signals colocalize with Iba1-positive cells. $\boldsymbol{A}, \boldsymbol{C}, \boldsymbol{E}$, Low-magnification images of ipsilateral side. $\boldsymbol{B}, \boldsymbol{D}, \boldsymbol{F}$, High-magnification images of ipsilateral side. Ipsi, Ipsilateral side; Contra, contralateral side. Scale bars: $A, C, E, 200 \mu \mathrm{m} ; \boldsymbol{B}, \boldsymbol{D}, \boldsymbol{F}, 20 \mu \mathrm{m}$. G-L, Comparison of pDAP12 immunoreactivity in ipsilateral DH of WT (G-I) and Dap $12^{-1-}$ mouse $(J-L) 7 \mathrm{~d}$ after $L 4$ nerve injury. Only WT ipsilateral DH has robust pDAP12 immunoreactivity. Scale bar, $200 \mu \mathrm{m}$. 
A

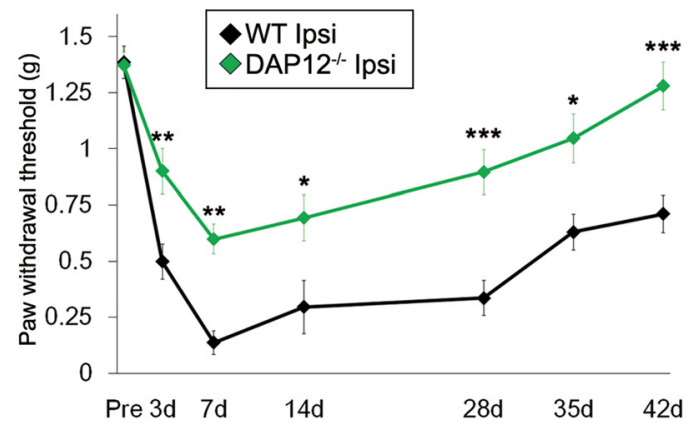

B

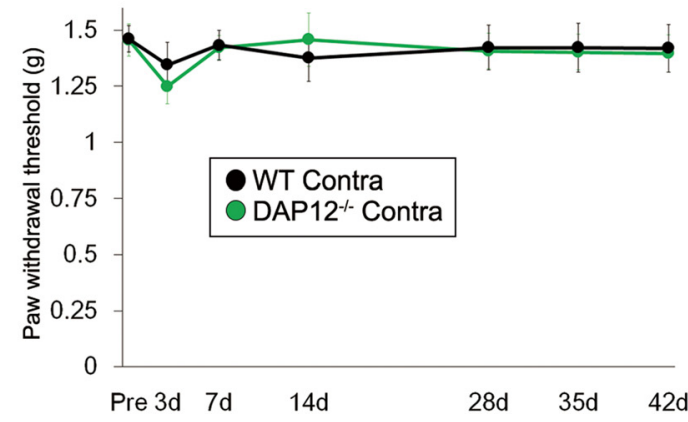

Figure 3. Nerve injury-induced mechanical allodynia is significantly reduced in Dap $12^{-/-}$mice. PWT in WT and Dap $12^{-/-}$mice before (pre) and after $L 4$ nerve injury $(n=7-10)$. $A$, PWT of ipsilateral side (Ipsi). B, PWT of contralateral side (Contra). ${ }^{*} p<0.05$ (two-way ANOVA with post hoc Turkey's test). ${ }^{* *} p<0.01$ (two-way ANOVA with post hoc Turkey's test). ${ }^{* * *} p<0.001$ (two-way ANOVA with post hoc Turkey's test). At all time points, PWT is greater in Dap $12^{-1-}$ mice than WT on the ipsilateral side.
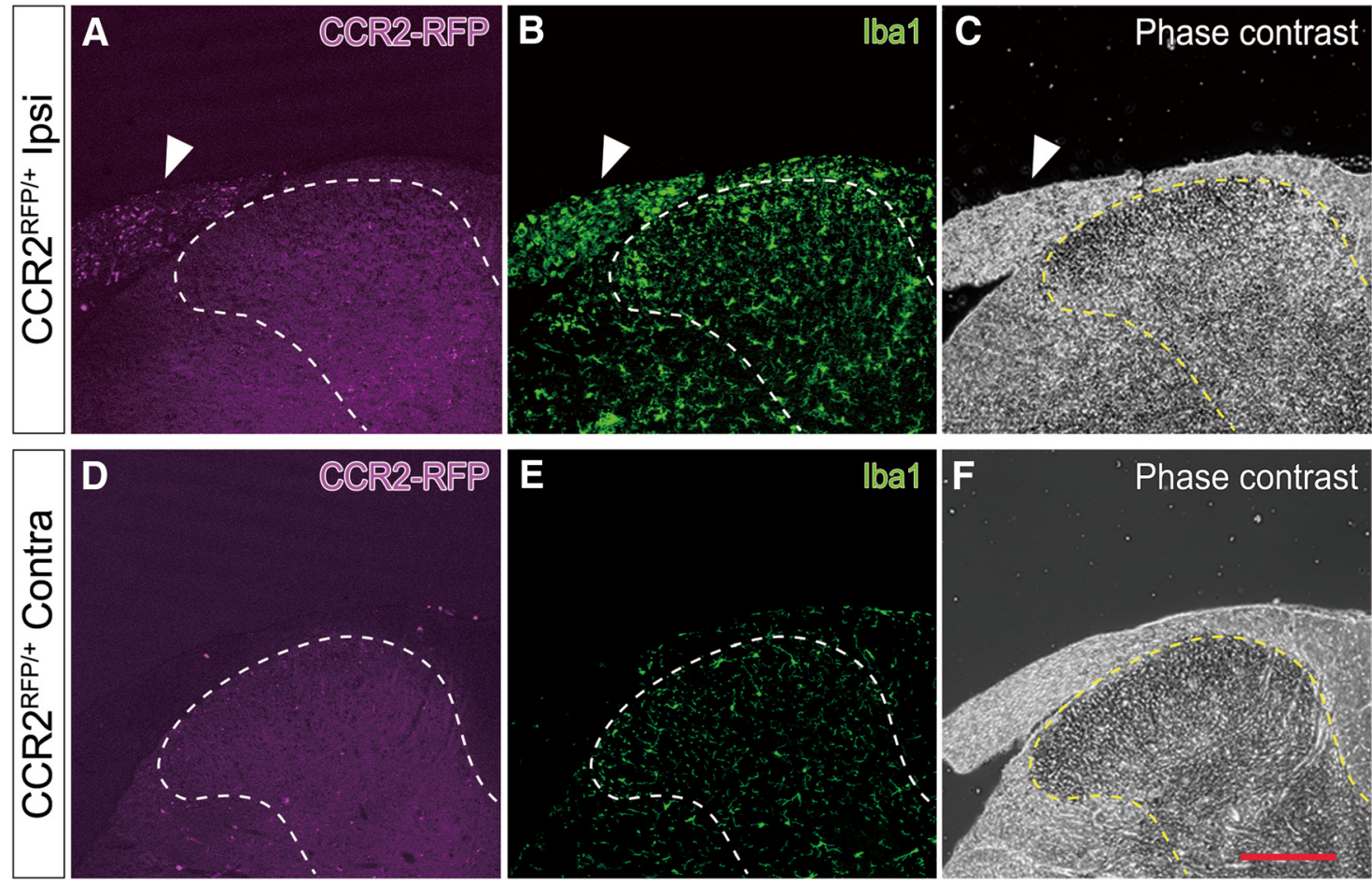

Figure 4. Peripheral monocytes do not infiltrate into spinal cord after $\mathrm{L} 4$ nerve injury. $\mathrm{L} 4 \mathrm{DH}$ with dorsal root of $C \mathrm{Cr} 2^{\mathrm{RFP} /+}$ mice $7 \mathrm{~d}$ after $\mathrm{L} 4$ nerve injury. CCR2 promoter-derived RFP signals $(\boldsymbol{A}, \boldsymbol{D}$, CCR2-RFP, magenta), Iba1 immunoreactivity ( $\boldsymbol{B}, \boldsymbol{E}$, green), and phase-contrast images $(\boldsymbol{C}, \boldsymbol{F})$ are shown. $\boldsymbol{A}-\boldsymbol{C}$, Ipsi, Ipsilateral side. $\boldsymbol{D}-\boldsymbol{F}$, Contra, Contralateral side. In the injured ipsilateral $\mathrm{L} 4$ spinal nerve, RFP signals are observed in Iba1-positive peripheral monocytes/macrophages (arrowheads). Conversely, in the ipsilateral DH, almost all Iba1-positive microglia are negative for RFP. In the contralateral side, CCR2 signals are barely visible in the spinal nerve and dorsal horn. Scale bar, $200 \mu \mathrm{m}$.

promoting expression of proinflammatory cytokines and other neuropathic pain-related genes.

\section{TREM2 role in DAP12-mediated signaling in neuropathic pain}

It is assumed that DAP12 is not involved in ligand binding because of its short extracellular domain. However, DAP12 is capable of mediating signals by forming complexes with DAP12associated receptors (Lanier, 2009). To identify the DAP12 partners in the present neuropathic pain model, we measured mRNA expression of known DAP12-associated receptors expressed by myeloid cells in the DH at $7 \mathrm{~d}$ after injury. Among the genes examined in Figure 7A, Trem2 and Csflr exhibited a significant induction (Fig. 7A), whereas other genes exhibited very low or no expression after nerve injury.
We focused on TREM 2 as a counterpart receptor of DAP 12 because CSF1R is considered to locate upstream of DAP12 (Zou et al., 2008; McVicar and Trinchieri, 2009), and no direct interaction between CSF1R and DAP12 has been reported (Hamerman et al., 2009). The Trem2 expression profile over time in DH tissue after injury was examined by qRT-PCR analysis. Peak expression was observed at 3 to $7 \mathrm{~d}$ after injury, with a 7.80 -fold increase compared with the nonoperated naive side at $3 \mathrm{~d}$ after injury (Fig. $7 B$ ). We then performed double-labeling with in situ hybridization for Trem2 mRNA and immunohistochemistry for IRF8. Hybridization signals for Trem 2 mRNA were observed in IRF8-positive cells (Fig. $7 C-G$ ), indicating that Trem $2 \mathrm{mRNA}$ is expressed by microglia and that TREM2 could function as a binding partner with DAP12 in microglia after nerve injury. 

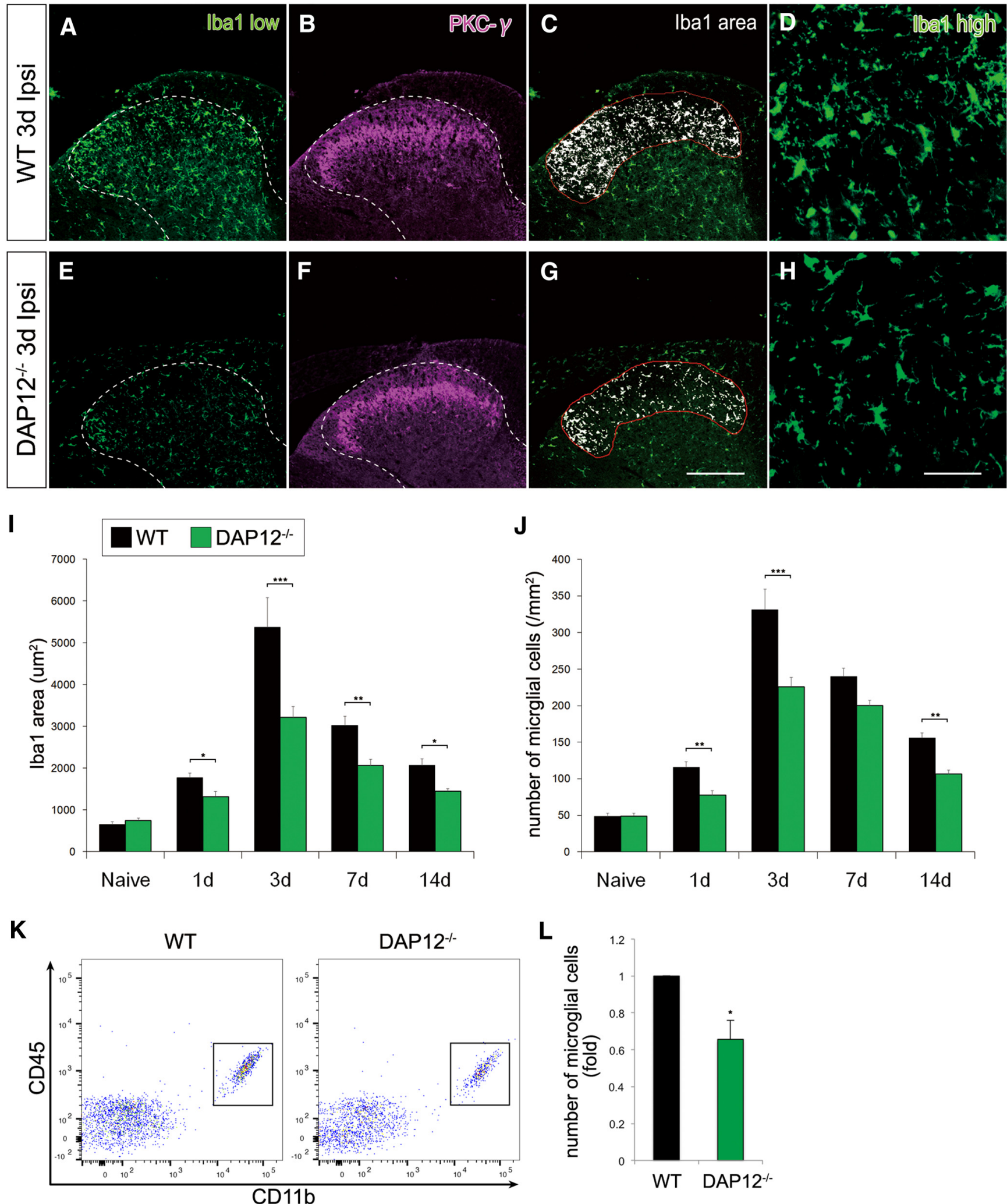

Figure 5. Microglial numbers are reduced in injured DH of Dap $12^{-1-}$ mice. $\boldsymbol{A}-\boldsymbol{H}$, Sections of ipsilateral DH in WT $(\boldsymbol{A}-\boldsymbol{D})$ and Dap $12^{-1-}(\boldsymbol{E}-\boldsymbol{H})$ mice $3 \mathrm{~d}$ after $L 4$ nerve injury were stained by anti-lba1 antibody $(\boldsymbol{A}, \boldsymbol{E}$, green) and anti-PKC $\boldsymbol{\gamma}$ antibody $(\boldsymbol{B}, \boldsymbol{F}$, magenta) for lamina II visualization. Iba1-positive area within lamina I and II is indicated in white $(\boldsymbol{C}, \boldsymbol{G})$. Higher magnification of Iba1 signals in lamina I and II is also shown $(\boldsymbol{D}, \boldsymbol{H})$. Scale bar, $200 \mu \mathrm{m}$ (left, middle left, and middle right columns), $20 \mu \mathrm{m}$ (right column). I, J, Quantification of Iba1-positive area $(\boldsymbol{I})$ and microglial numbers $(\boldsymbol{J})$ in lamina I and II of ipsilateral L 4 DH in WT and Dap $12^{-1-}$ mice before (Naive) and after $\mathrm{L} 4$ nerve injury ( $n=3$ for each time point). Values are mean \pm SEM. ${ }^{*} p<0.05$ (two-way ANOVA with post hoc Turkey's test). ${ }^{* *} p<0.01$ (two-way ANOVA with post hoc Turkey's test). ${ }^{* *} p<0.001$ (two-way ANOVA with post hoc Turkey's test). $\boldsymbol{K}$, Flow cytometric analysis of $\mathrm{CD}_{11 \mathrm{~b}^{+}} / \mathrm{CD} 45^{\text {low }}$ microglia in ipsilateral L4 DH $3 \mathrm{~d}$ after injury. Representative data are shown. CD11b ${ }^{+} / \mathrm{CD}_{4} 5^{\text {high }}$ monocytes/macrophages were hardly seen in DH tissues. $L$, Fold changes of microglial numbers in ipsilateral L4 DH $3 \mathrm{~d}$ after injury determined by flow cytometry. Microglial numbers were normalized to that of fluorospheres, and then the ratio (Dap $12^{-1-} /$ WT) was calculated $(n=5)$. Values are mean \pm SEM. ${ }^{*} p<0.05$ (paired Student's $t$ test). 

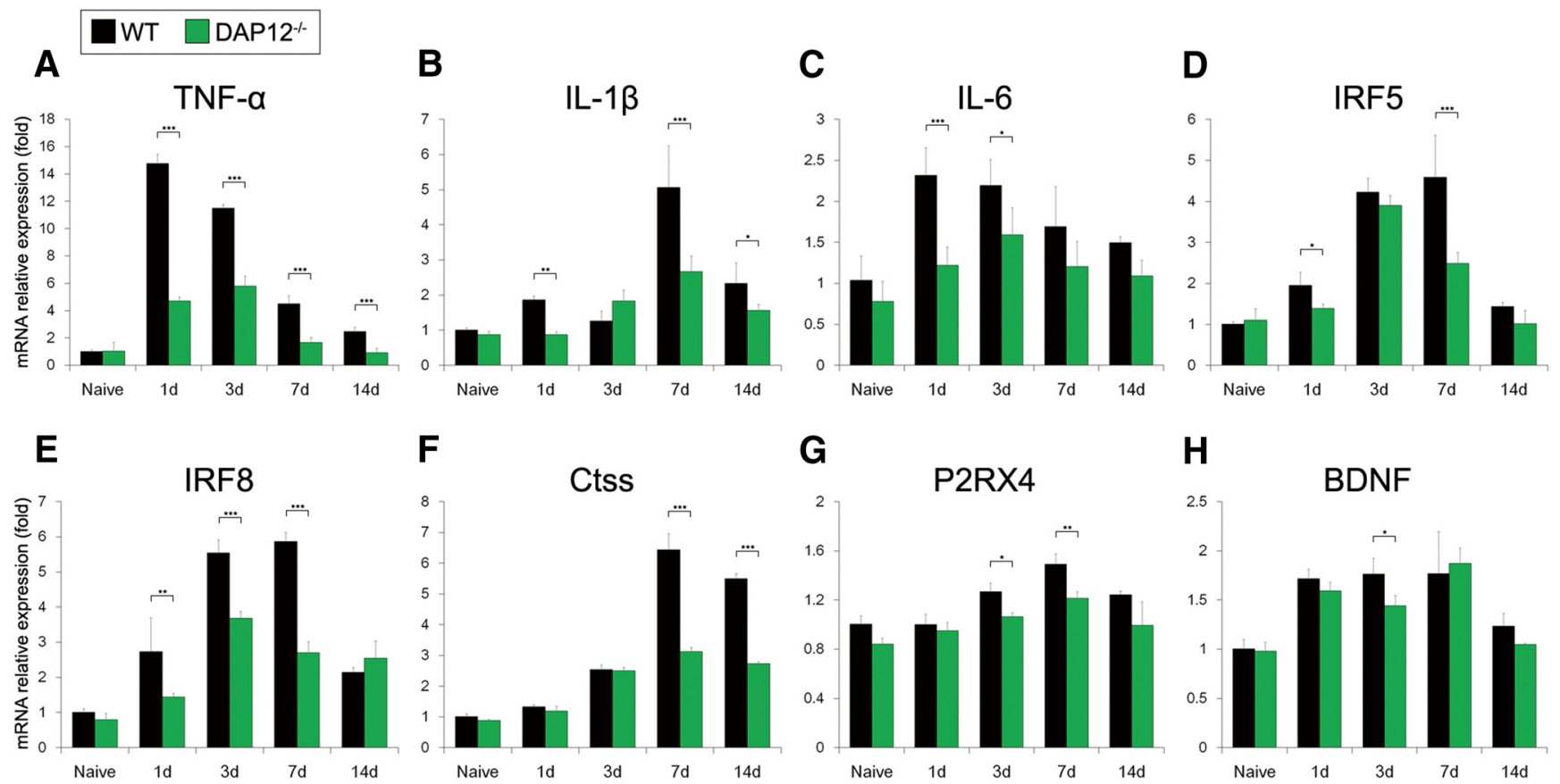

Figure 6. Neuropathic pain-related microglial molecules are suppressed in Dap $12^{-1-}$ mice. Ipsilateral L4 DH was obtained from WT and Dap $12^{-1-}$ mice before (Naive) and after $\mathrm{L} 4$ nerve injury $(n=4)$, and mRNA expression of neuropathic pain-related molecules as quantified by qRT-PCR. $\boldsymbol{A}, \operatorname{Tnfa} ; \boldsymbol{B}, I I 1 b ; \boldsymbol{C}, I I 6 ; \boldsymbol{D}$, Irf5; $\boldsymbol{E}$, Irff; $\boldsymbol{F}$, Ctss; $\boldsymbol{G}, P 2 r x 4 ; \boldsymbol{H}, B d n f$. Results are normalized to Gapdh and shown as ratios to nonoperated value in WT mice. Values are mean \pm SEM. ${ }^{*} p<0.05$ (two-way ANOVA with post hoc Turkey's test). ${ }^{* *} p<0.01$ (two-way ANOVA with post hoc Turkey's test). ${ }^{* *} p<0.001$ (two-way ANOVA with post hoc Turkey's test).
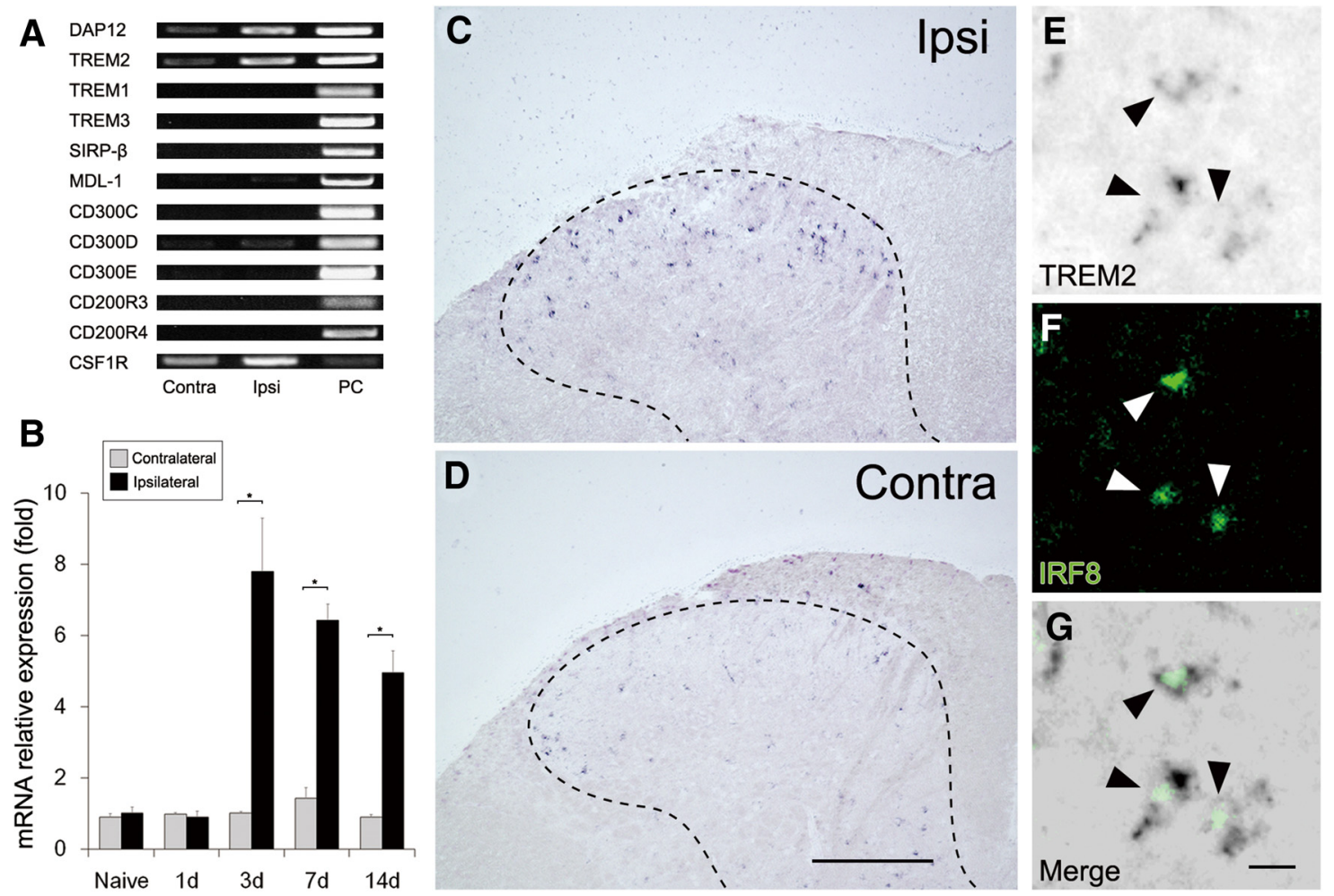

Figure 7. DAP12-associated receptor TREM2 is induced in microglia after nerve injury. $A$, Conventional RT-PCR results of DAP12-associated receptors expressed by myeloid cells. In addition to cDNA prepared from ipsilateral (Ipsi) and contralateral (Contra) DH $7 \mathrm{~d}$ after L4 nerve injury, positive control (PC) tissues, such as spleen, were used. $\boldsymbol{B}$, qRT-PCR analysis of Trem2 mRNA extracted from contralateral and ipsilateral L 4 DH of WT mice before (Naive) and after L4 nerve injury. Results are normalized to Gapdh ( $n=4$ for each time point). Values are mean \pm SEM. ${ }^{*} p<0.001$ (two-way ANOVA with post hoc Turkey's test). $C, D$, In situ hybridization shows induction of Trem $2 \mathrm{mRNA}$ expression in the spinal DH $7 \mathrm{~d}$ after $\mathrm{L} 4 \mathrm{nerve}$ injury (low-magnification images). C, Ipsi, Ipsilateral side. D, Contra, Contralateral side. Scale bar, $200 \mu \mathrm{m}$. E-G, Localization of Trem2 mRNA in microglia in L4 DH (high-magnification images). Hybridized cells $(\boldsymbol{E})$ have IRF8 immunoreactivity $(\boldsymbol{F})$ in their nuclei (arrowheads). Scale bar, $10 \mu \mathrm{m}$. 
A
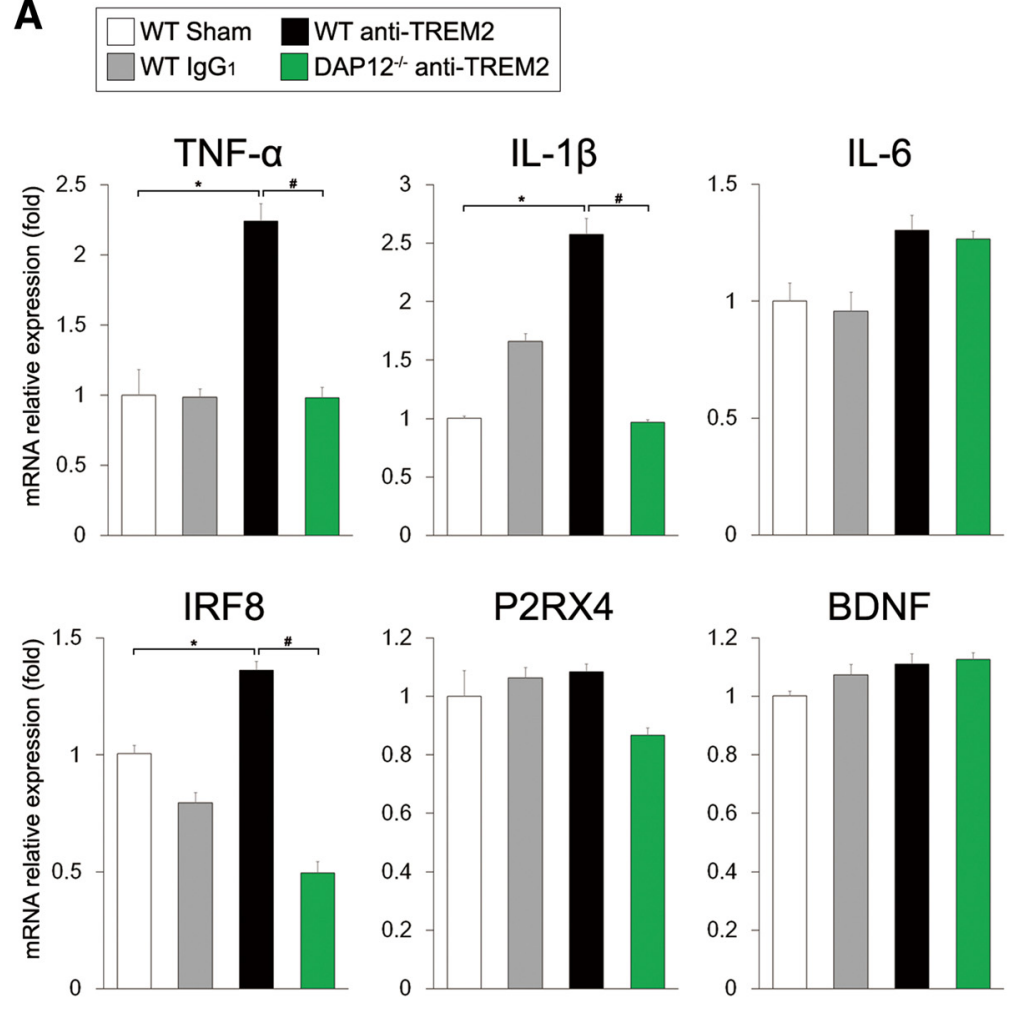

B
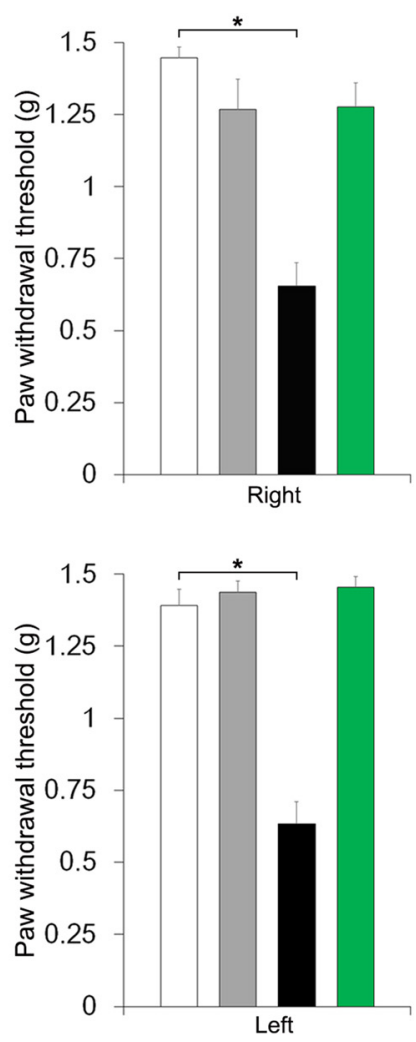

Figure 8. Intrathecal administration of TREM2 agonistic antibody induces mechanical allodynia via DAP12. A, qRT-PCR analysis of neuropathic pain-related microglial molecules in L4 DH of noninjured WT and Dap 12 ${ }^{-1-}$ mice after intrathecal administration of TREM2 agonistic antibody (anti-TREM2) or control lgG $\left(\operatorname{lgG}_{1}\right)$ for 3 consecutive days. Results are normalized to Gapdh ( $n=$ 4 for each time point). Values are mean \pm SEM. ${ }^{*} p<0.001$ versus WT Sham (one-way ANOVA with post hoc Turkey's test). ${ }^{\#} p<0.001$ versus WT anti-TREM2 (one-way ANOVA with post hoc Turkey's test). $\boldsymbol{B}$, PWT for right and left paw of mice intrathecally administered TREM2 agonistic antibody for 3 consecutive days $(n=7$ or 8$)$. Values are mean \pm SEM. . $p<0.001$ versus WT Sham (one-way ANOVA with post hoc Turkey's test).

To determine the functional involvement of TREM2 in neuropathic pain, we examined the effect of intrathecal administration of agonistic TREM2 antibody in noninjured WT mice (Fig. 8). This monoclonal antibody is reported to cross-link TREM2 on the cellular surface and exert DAP12 signaling (Humphrey et al., 2006). Tnfa, Illb, and Irf8 mRNA expression levels were upregulated in the $\mathrm{DH}$ after 3 consecutive days of TREM 2 antibody administration compared with the sham-operated group (Tnfa: $p=9.0 \times 10^{-6} ;$ Illb: $p=7.2 \times 10^{-13} ;$ Irfs: $p=7.1 \times 10^{-13}$, one-way ANOVA with post hoc Turkey's test). However, these expression changes were not observed in the Dap $12^{-1-}$ mice (Fig. 8A). Additionally, PWTs in the TREM2 administration group were significantly less than in the control groups and Dap $12^{-1-}$ mice, indicating that the TREM2 agonistic antibody induced pain behavior without nerve injury (right paw: $p=7.9 \times$ $10^{-7}$; left paw: $p=1.5 \times 10^{-9}$; vs WT sham-operated group, one-way ANOVA with post hoc Turkey's test), and that this type of pain induction was DAP12-dependent (Fig. 8B).

\section{Discussion}

Results from the present study revealed a critical role for DAP 12 and its associated receptor TREM2 in neuropathic pain. Both DAP12 and TREM2 were expressed by microglia (Figs. 1, 7), and DAP12 were phosphorylated in activated microglia in response to nerve injury (Fig. 2). These results suggested that DAP12mediated signaling is induced in microglia after nerve injury. Consistent with these results, Dap12 deficiency also suppressed nerve injury-induced mechanical allodynia and TREM2 activation induced allodynia (Figs. 3, 8B), suggesting that microglial
TREM2/DAP12-mediated signaling contributes to the development and persistence of neuropathic pain.

\section{DAP12 signaling in microglia}

In the CNS, DAP12 is predominantly expressed by microglia (Fig. 1). Results from the present study showed that Dap12 mRNA levels (Fig. $1 A-C$ ) and microglial numbers simultaneously increase in response to sensory nerve injury. Because the fold changes of the mRNA expression in the ipsilateral DH after injury (Fig. 1A) were equivalent to those of microglial numbers (Fig. $5 J-L$ ), the increase in Dap12 mRNA in the ipsilateral DH may be due to increased number of microglia rather than upregulated expression. The phosphorylation of tyrosine residues within the ITAM motifs of DAP12 was significantly induced in microglia in response to sensory nerve injury (Fig. 2), suggesting that DAP12 activation elicits further intracellular signals. Several signaling pathways, such as mitogen-activated protein kinases, phospholipase $\mathrm{C} \gamma$, PKC, phosphoinositide 3 kinase, and nuclear factor- $\kappa \mathrm{B}$, are associated with proinflammatory responses, phagocytosis, and microglial migration and proliferation (Xing et al., 2015). In particular, induction of proinflammatory cytokines and their associated molecules in microglia could result in a phenotypic shift to a toxic phenotype, resulting in neuronal damage (Maeda et al., 2010; Kobayashi et al., 2015). We clearly demonstrated that nerve injury increases mRNA expression of proinflammatory cytokines, such as Tnfa, $I l 1 b$, and $I l 6$, as well as other factors associated with neuropathic pain, such as Irf5, Irf8, and Ctss in the ipsilateral DH; however, expression of these genes was suppressed in Dap12-deficient mice (Fig. 6). The decreases in the expression of these molecules were greater than the decreases in microglial num- 
bers at the expression peak (Fig. $5 J$ ), suggesting that expression of those proinflammatory molecules might be suppressed in activated microglia in Dap12-deficient mice. These results are in line with our previous study demonstrating downregulation of proinflammatory molecules in LPS-activated cultured microglia of Dap12-deficient mice (Kobayashi et al., 2015). Dap12 deficiency likely suppresses excessive activation of microglia and reduced allodynia (Fig. 3).

Recently, Guan et al. (2016) demonstrated through the use of BrdU labeling that Dap12 (Tyrobp) deletion has no effect on nerve injury-induced microglial proliferation. However, our findings showed decreased microglial cell numbers and the area of Ibal expression in the DH of Dap12-deficient mice (Fig. 5). Our findings suggest that the increased microglial cell number and occupying area are due to microglial migration from surrounding areas or changes in the rate of microglial survival. DAP12 has been proposed to be involved in cytoskeletal remodeling and migration in other cells (Turnbull and Colonna, 2007), which supports the theory that suppression of microglial migration in DAP12-deficient mice is likely. Additionally, Dap12deficient mice had fewer microglia in the spinal cord and exhibited microglial degeneration and apoptotic cell death features at 10 months of age, suggesting that microglial survival is diminished in Dap12-deficient mice (Otero et al., 2009). Furthermore, Wang et al. (2015) demonstrated a role for TREM2 in maintaining microglial survival during reactive microgliosis using Trem2-deficient Alzheimer's disease model mice. Nevertheless, further studies are needed to determine the mechanisms involved in the decreased microglial numbers observed in this study.

\section{The DAP12 counterpart receptor}

DAP12 consists of a short extracellular domain, a single transmembrane domain, and a cytoplasmic ITAM, and has been identified as the signaling chain for some ligand-binding receptors. More than 30 receptor chains have been shown to be associated with DAP12 (Lanier, 2009). Among the associated receptors examined, the mRNA expression profile for Trem2 and Csf1r was most similar to Dap12 mRNA levels in our allodynia model (Figs. $1 A, 7 A, B)$. While preparing this article, a report was published showing that DAP12 is responsible for microglial CSF1Rinduced neuropathic pain (Guan et al., 2016). In terms of pain sensation, they demonstrated that DAP12 is located downstream of CSF1R, whereas we showed that TREM2 is a potent counterpart receptor of DAP12. Although no direct interaction between CSF1R and DAP12 has been reported (Hamerman et al., 2009), CSF1R is considered an activator of Src tyrosine kinase, which phosphorylates the ITAM motif of DAP12 (Zou et al., 2008; McVicar and Trinchieri, 2009). Therefore, DAP12 could be located at a position of signal convergence between CSF1Rmediated and TREM2-mediated signals. Their findings primarily support our data showing that the microglial DAP12 pathway plays a critical role in neuropathic pain development. It is likely that multiple signals associated with pain sensation converge at DAP12 because CSF1R and TREM2 are abundantly expressed by microglia after nerve injury (Fig. 7), and Dap12 deficiency suppressed the receptor-mediated pain behavior of these two molecules (Fig. 3) (Guan et al., 2016). Although the significance of DAP12 in pain sensation is supported by both studies, Guan et al. (2016) demonstrated almost total suppression of pain behavior in Dap12 knock-out mice, whereas our Dap12 knock-out mice exhibited partial, but significant, suppression of pain behavior (Fig. 3). These differences could be due to differences between animal models used.

\section{TREM2 function}

As with Dap12 mRNA, the rate of increase in Trem 2 mRNA in the injured ipsilateral DH (Fig. $7 B$ ) was nearly equal to those of microglial numbers (Fig. 5J-L) at the expression peak, suggesting that TREM 2 may be expressed by and function in microglia in a similar manner between steady and an activation states. Trem2 was recently reported to be a causative gene of Alzheimer's disease (Guerreiro et al., 2013; Jonsson et al., 2013), Parkinson's disease (Rayaprolu et al., 2013), and amyotrophic lateral sclerosis (Cady et al., 2014). Because TREM2 is expressed by microglia, these neurodegenerative diseases are assumed to be partly associated with microglial disorders. TREM2 has been identified as a phagocytic receptor in an experimental autoimmune encephalomyelitis model (Takahashi et al., 2005) and ischemia model (Kawabori et al., 2015), and TREM2 signals sustain microglial responses by promoting microglia survival in an Alzheimer's disease model (Wang et al., 2015). TREM2 is assumed to be an essential molecule that determines microglial phenotype and activation status. Therefore, microglial alteration by TREM2 signaling could lead to neuropathic pain. In the present study, intrathecal administration of agonistic TREM2 antibody elicited pain behavior in mice without nerve injury, and this pain behavior was totally abolished in Dap12-deficient mice (Fig. 8B), suggesting that TREM2 signaling is predominantly transferred to DAP12. Concomitantly induced expression of proinflammatory cytokine genes have been observed in the DH after nerve injury, although these inductions do not occur in Dap12-deficient mice (Fig. 8A). Together, DAP12-mediated signals could be one of key pathways in pain signaling.

Although the ligand that binds to and activates TREM2 remains elusive, a broad array of lipids produced directly or indirectly as a result of damage to primary sensory neurons has been proposed as potential TREM2 ligands (Wang et al., 2015). TREM 2 could serve as a microglial sensor for lipid mediators that are released from damaged sensory nerve terminals or other cells in the $\mathrm{DH}$. Recently, apolipoprotein $\mathrm{E}$ (ApoE) was reported to be a potent ligand for TREM2, and an Alzheimer's diseaseassociated $\mathrm{R} 47 \mathrm{H}$ mutation and other artificial mutations introduced at the same location significantly reduce the affinity of TREM2 for ApoE (Atagi et al., 2015; Bailey et al., 2015). Additionally, ApoE protein was shown to be upregulated in injured DRG neurons in a spinal nerve ligation model (Melemedjian et al., 2013). These reports suggest that ApoE could be a potent activator of the TREM2/DAP12 system in the present pain model. Furthermore, recent evidence shows that exosomes play important roles in intercellular communication networks, enabling the exchange of information, as well as proteins and lipids, between producing cells and target cells (Turturici et al., 2014). Cortical neurons (Fauré et al., 2006), microglia (Potolicchio et al., 2005), and astrocytes (Frühbeis et al., 2013) release exosomes. The activation of transcription factor EB, a key transcription factor for lysosomal exocytosis (Medina et al., 2011), together with lysosome transportation into central branches of DRG neurons, has been observed in nerve-injured DRG neurons (Jung et al., 2016). Those findings suggest that exosomes and lysosomes released from primary sensory nerve terminals after nerve injury are additional source of lipids for TREM2 activation, although other ligands, such as nucleic acids, may exist for microglial TREM2 activation (Kawabori et al., 2015).

In conclusion, this study provides evidence that DAP12 could be a key microglial membrane molecule that modulates microglial function and elicits abnormal pain after sensory nerve injury. Our results demonstrated that TREM2 is a partner receptor 
for microglial activation, although additional receptor-mediated pathways, such as CSF1R, may also be involved in DAP12mediated microglial activation. DAP12 and TREM2 could serve as potential therapeutic targets for neuropathic pain, although further studies are needed to determine the mechanisms of TREM2/DAP12 intracellular signaling.

\section{References}

Atagi Y, Liu CC, Painter MM, Chen XF, Verbeeck C, Zheng H, Li X, Rademakers R, Kang SS, Xu H, Younkin S, Das P, Fryer JD, Bu G (2015) Apolipoprotein $\mathrm{E}$ is a ligand for triggering receptor expressed on myeloid cells 2 (TREM2). J Biol Chem 290:26043-26050. CrossRef Medline

Bailey CC, DeVaux LB, Farzan M (2015) The triggering receptor expressed on myeloid cells 2 binds apolipoprotein E. J Biol Chem 290:26033-26042. CrossRef Medline

Bouchon A, Hernández-Munain C, Cella M, Colonna M (2001) A DAP12mediated pathway regulates expression of CC chemokine receptor 7 and maturation of human dendritic cells. J Exp Med 194:1111-1122. CrossRef Medline

Braissant O, Wahli W (1998) A simplified in situ hybridization protocol using non-radioactively labeled probes to detect abundant and rare mRNAs on tissue sections. Biochemica 1:10-16.

Cady J, Koval ED, Benitez BA, Zaidman C, Jockel-Balsarotti J, Allred P, Baloh RH, Ravits J, Simpson E, Appel SH, Pestronk A, Goate AM, Miller TM, Cruchaga C, Harms MB (2014) TREM2 variant p.R47H as a risk factor for sporadic amyotrophic lateral sclerosis. JAMA Neurol 71:449-453. CrossRef Medline

Chaplan SR, Bach FW, Pogrel JW, Chung JM, Yaksh TL (1994) Quantitative assessment of tactile allodynia in the rat paw. J Neurosci Methods 53:5563. CrossRef Medline

Clark AK, Yip PK, Grist J, Gentry C, Staniland AA, Marchand F, Dehvari M, Wotherspoon G, Winter J, Ullah J, Bevan S, Malcangio M (2007) Inhibition of spinal microglial cathepsin $\mathrm{S}$ for the reversal of neuropathic pain. Proc Natl Acad Sci U S A 104:10655-10660. CrossRef Medline

Coull JA, Beggs S, Boudreau D, Boivin D, Tsuda M, Inoue K, Gravel C, Salter MW, De Koninck Y (2005) BDNF from microglia causes the shift in neuronal anion gradient underlying neuropathic pain. Nature 438:10171021. CrossRef Medline

Fauré J, Lachenal G, Court M, Hirrlinger J, Chatellard-Causse C, Blot B, Grange J, Schoehn G, Goldberg Y, Boyer V, Kirchhoff F, Raposo G, Garin J, Sadoul R (2006) Exosomes are released by cultured cortical neurones. Mol Cell Neurosci 31:642-648. CrossRef Medline

Frühbeis C, Fröhlich D, Kuo WP, Kramer-Albers EM (2013) Extracellular vesicles as mediators of neuron-glia communication. Front Cell Neurosci 7:182. CrossRef Medline

Grace PM, Hutchinson MR, Maier SF, Watkins LR (2014) Pathological pain and the neuroimmune interface. Nat Rev Immunol 14:217-231. CrossRef Medline

Guan Z, Kuhn JA, Wang X, Colquitt B, Solorzano C, Vaman S, Guan AK, Evans-Reinsch Z, Braz J, Devor M, Abboud-Werner SL, Lanier LL, Lomvardas S, Basbaum AI (2016) Injured sensory neuron-derived CSF1 induces microglial proliferation and DAP12-dependent pain. Nat Neurosci 19:94-101. CrossRef Medline

Guerreiro R, Wojtas A, Bras J, Carrasquillo M, Rogaeva E, Majounie E, Cruchaga C, Sassi C, Kauwe JS, Younkin S, Hazrati L, Collinge J, Pocock J, Lashley T, Williams J, Lambert JC, Amouyel P, Goate A, Rademakers R, Morgan K, et al. (2013) TREM2 variants in Alzheimer's disease. N Engl J Med 368:117-127. CrossRef Medline

Hamerman JA, Ni M, Killebrew JR, Chu CL, Lowell CA (2009) The expanding roles of ITAM adapters FcRgamma and DAP12 in myeloid cells. Immunol Rev 232:42-58. CrossRef Medline

He XH, Zang Y, Chen X, Pang RP, Xu JT, Zhou X, Wei XH, Li YY, Xin WJ, Qin ZH, Liu XG (2010) TNF-alpha contributes to up-regulation of Nav1.3 and Nav1.8 in DRG neurons following motor fiber injury. Pain 151:266279. CrossRef Medline

Humphrey MB, Daws MR, Spusta SC, Niemi EC, Torchia JA, Lanier LL, Seaman WE, Nakamura MC (2006) TREM2, a DAP12-associated receptor, regulates osteoclast differentiation and function. J Bone Miner Res 21:237-245. CrossRef Medline

Inoue K, Tsuda M (2009) Microglia and neuropathic pain. Glia 57:14691479. CrossRef Medline

Jonsson T, Stefansson H, Steinberg S, Jonsdottir I, Jonsson PV, Snaedal J,
Bjornsson S, Huttenlocher J, Levey AI, Lah JJ, Rujescu D, Hampel H, Giegling I, Andreassen OA, Engedal K, Ulstein I, Djurovic S, IbrahimVerbaas C, Hofman A, Ikram MA, et al. (2013) Variant of TREM2 associated with the risk of Alzheimer's disease. N Engl J Med 368:107-116. CrossRef Medline

Jung J, Uesugi N, Jeong NY, Park BS, Konishi H, Kiyama H (2016) Increase of transcription factor EB (TFEB) and lysosomes in rat DRG neurons and their transportation to the central nerve terminal in dorsal horn after nerve injury. Neuroscience 313:10-22. CrossRef Medline

Kaifu T, Nakahara J, Inui M, Mishima K, Momiyama T, Kaji M, Sugahara A, Koito H, Ujike-Asai A, Nakamura A, Kanazawa K, Tan-Takeuchi K, Iwasaki K, Yokoyama WM, Kudo A, Fujiwara M, Asou H, Takai T (2003) Osteopetrosis and thalamic hypomyelinosis with synaptic degeneration in DAP12-deficient mice. J Clin Invest 111:323-332. CrossRef Medline

Kawabori M, Kacimi R, Kauppinen T, Calosing C, Kim JY, Hsieh CL, Nakamura MC, Yenari MA (2015) Triggering receptor expressed on myeloid cells 2 (TREM2) deficiency attenuates phagocytic activities of microglia and exacerbates ischemic damage in experimental stroke. J Neurosci 35 : 3384-3396. CrossRef Medline

Kim SH, Chung JM (1992) An experimental model for peripheral neuropathy produced by segmental spinal nerve ligation in the rat. Pain 50: 355-363. CrossRef Medline

Kobayashi M, Konishi H, Takai T, Kiyama H (2015) A DAP12-dependent signal promotes pro-inflammatory polarization in microglia following nerve injury and exacerbates degeneration of injured neurons. Glia 63: 1073-1082. CrossRef Medline

Konishi H, Namikawa K, Kiyama H (2006) Annexin III implicated in the microglial response to motor nerve injury. Glia 53:723-732. CrossRef Medline

Krausgruber T, Blazek K, Smallie T, Alzabin S, Lockstone H, Sahgal N, Hussell T, Feldmann M, Udalova IA (2011) IRF5 promotes inflammatory macrophage polarization and TH1-TH17 responses. Nat Immunol 12:231238. CrossRef Medline

Lanier LL (2009) DAP10- and DAP12-associated receptors in innate immunity. Immunol Rev 227:150-160. CrossRef Medline

Leung L, Cahill CM (2010) TNF-alpha and neuropathic pain: a review. J Neuroinflammation 7:27. CrossRef Medline

Maeda M, Tsuda M, Tozaki-Saitoh H, Inoue K, Kiyama H (2010) Nerve injury-activated microglia engulf myelinated axons in a P2Y12 signalingdependent manner in the dorsal horn. Glia 58:1838-1846. CrossRef Medline

Malmberg AB, Chen C, Tonegawa S, Basbaum AI (1997) Preserved acute pain and reduced neuropathic pain in mice lacking PKCgamma. Science 278:279-283. CrossRef Medline

Masuda T, Tsuda M, Yoshinaga R, Tozaki-Saitoh H, Ozato K, Tamura T, Inoue $\mathrm{K}$ (2012) IRF8 is a critical transcription factor for transforming microglia into a reactive phenotype. Cell Rep 1:334-340. CrossRef Medline

Masuda T, Iwamoto S, Yoshinaga R, Tozaki-Saitoh H, Nishiyama A, Mak TW, Tamura T, Tsuda M, Inoue K (2014) Transcription factor IRF5 drives P2X4R(+)-reactive microglia gating neuropathic pain. Nat Commun 5:3771-3782. CrossRef Medline

McVicar DW, Trinchieri G (2009) CSF-1R, DAP12 and beta-catenin: a menage a trois. Nat Immunol 10:681-683. CrossRef Medline

Medina DL, Fraldi A, Bouche V, Annunziata F, Mansueto G, Spampanato C, Puri C, Pignata A, Martina JA, Sardiello M, Palmieri M, Polishchuk R, Puertollano R, Ballabio A (2011) Transcriptional activation of lysosomal exocytosis promotes cellular clearance. Dev Cell 21:421-430. CrossRef Medline

Melemedjian OK, Yassine HN, Shy A, Price TJ (2013) Proteomic and functional annotation analysis of injured peripheral nerves reveals ApoE as a protein upregulated by injury that is modulated by metformin treatment. Mol Pain 9:14. CrossRef Medline

Nakadate Y, Uchida K, Shikata K, Yoshimura S, Azuma M, Hirata T, Konishi H, Kiyama H, Tachibana T (2009) The formation of argpyrimidine, a methylglyoxal-arginine adduct, in the nucleus of neural cells. Biochem Biophys Res Commun 378:209-212. CrossRef Medline

Otero K, Turnbull IR, Poliani PL, Vermi W, Cerutti E, Aoshi T, Tassi I, Takai T, Stanley SL, Miller M, Shaw AS, Colonna M (2009) Macrophage colony-stimulating factor induces the proliferation and survival of macrophages via a pathway involving DAP12 and beta-catenin. Nat Immunol 10:734-743. CrossRef Medline 
Paloneva J, Kestilä M, Wu J, Salminen A, Böhling T, Ruotsalainen V, Hakola P, Bakker AB, Phillips JH, Pekkarinen P, Lanier LL, Timonen T, Peltonen L (2000) Loss-of-function mutations in TYROBP (DAP12) result in a presenile dementia with bone cysts. Nat Genet 25:357-361. CrossRef Medline

Peng Q, Malhotra S, Torchia JA, Kerr WG, Coggeshall KM, Humphrey MB (2010) TREM2- and DAP12-dependent activation of PI3K requires DAP10 and is inhibited by SHIP1. Sci Signal 3:ra38. CrossRef Medline

Potolicchio I, Carven GJ, Xu X, Stipp C, Riese RJ, Stern LJ, Santambrogio L (2005) Proteomic analysis of microglia-derived exosomes: metabolic role of the aminopeptidase CD13 in neuropeptide catabolism. J Immunol 175:2237-2243. CrossRef Medline

Rayaprolu S, Mullen B, Baker M, Lynch T, Finger E, Seeley WW, Hatanpaa KJ, Lomen-Hoerth C, Kertesz A, Bigio EH, Lippa C, Josephs KA, Knopman DS, White CL 3rd, Caselli R, Mackenzie IR, Miller BL, Boczarska-Jedynak M, Opala G, Krygowska-Wajs A, et al. (2013) TREM2 in neurodegeneration: evidence for association of the p.R47H variant with frontotemporal dementia and Parkinson's disease. Mol Neurodegener 8:19. CrossRef Medline

Roumier A, Béchade C, Poncer JC, Smalla KH, Tomasello E, Vivier E, Gundelfinger ED, Triller A, Bessis A (2004) Impaired synaptic function in the microglial KARAP/DAP12-deficient mouse. J Neurosci 24:1142111428. CrossRef Medline

Saederup N, Cardona AE, Croft K, Mizutani M, Cotleur AC, Tsou CL, Ransohoff RM, Charo IF (2010) Selective chemokine receptor usage by central nervous system myeloid cells in CCR2-red fluorescent protein knock-in mice. PLoS One 5:e13693. CrossRef Medline

Siebert H, Sachse A, Kuziel WA, Maeda N, Brück W (2000) The chemokine receptor CCR2 is involved in macrophage recruitment to the injured peripheral nervous system. J Neuroimmunol 110:177-185. CrossRef Medline

Singh V, Mitra S, Sharma AK, Gera R, Ghosh D (2014) Isolation and characterization of microglia from adult mouse brain: selected applications for ex vivo evaluation of immunotoxicological alterations following in vivo xenobiotic exposure. Chem Res Toxicol 27:895-903. CrossRef Medline

Takahashi K, Rochford CD, Neumann H (2005) Clearance of apoptotic neurons without inflammation by microglial triggering receptor expressed on myeloid cells-2. J Exp Med 201:647-657. CrossRef Medline

Takaki R, Watson SR, Lanier LL (2006) DAP12: an adapter protein with dual functionality. Immunol Rev 214:118-129. CrossRef Medline

Takaoka A, Yanai H, Kondo S, Duncan G, Negishi H, Mizutani T, Kano S, Honda K, Ohba Y, Mak TW, Taniguchi T (2005) Integral role of IRF-5 in the gene induction programme activated by Toll-like receptors. Nature 434:243-249. CrossRef Medline

Thrash JC, Torbett BE, Carson MJ (2009) Developmental regulation of TREM2 and DAP12 expression in the murine CNS: implications for Nasu-Hakola disease. Neurochem Res 34:38-45. CrossRef Medline

Tomasello E, Olcese L, Vely F, Geourgeon C, Bléry M, Moqrich A, Gautheret
D, Djabali M, Mattei MG, Vivier E (1998) Gene structure, expression pattern, and biological activity of mouse killer cell activating receptorassociated protein (KARAP)/DAP-12. J Biol Chem 273:34115-34119. CrossRef Medline

Tsuda M, Shigemoto-Mogami Y, Koizumi S, Mizokoshi A, Kohsaka S, Salter MW, Inoue K (2003) P2X4 receptors induced in spinal microglia gate tactile allodynia after nerve injury. Nature 424:778-783. CrossRef Medline

Tsuda M, Inoue K, Salter MW (2005) Neuropathic pain and spinal microglia: a big problem from molecules in "small" glia. Trends Neurosci 28 : 101-107. CrossRef Medline

Tsuda M, Masuda T, Tozaki-Saitoh H, Inoue K (2013) P2X4 receptors and neuropathic pain. Front Cell Neurosci 7:191. CrossRef Medline

Turnbull IR, Colonna M (2007) Activating and inhibitory functions of DAP12. Nat Rev Immunol 7:155-161. CrossRef Medline

Turnbull IR, McDunn JE, Takai T, Townsend RR, Cobb JP, Colonna M (2005) DAP12 (KARAP) amplifies inflammation and increases mortality from endotoxemia and septic peritonitis. J Exp Med 202:363-369. CrossRef Medline

Turturici G, Tinnirello R, Sconzo G, Geraci F (2014) Extracellular membrane vesicles as a mechanism of cell-to-cell communication: advantages and disadvantages. Am J Physiol Cell Physiol 306:C621-633. CrossRef Medline

Wang Y, Cella M, Mallinson K, Ulrich JD, Young KL, Robinette ML, Gilfillan S, Krishnan GM, Sudhakar S, Zinselmeyer BH, Holtzman DM, Cirrito JR, Colonna M (2015) TREM2 lipid sensing sustains the microglial response in an Alzheimer's disease model. Cell 160:1061-1071. CrossRef Medline

Woolf CJ, Mannion RJ (1999) Neuropathic pain: aetiology, symptoms, mechanisms, and management. Lancet 353:1959-1964. CrossRef Medline

Xing J, Titus AR, Humphrey MB (2015) The TREM2-DAP12 signaling pathway in Nasu-Hakola disease: a molecular genetics perspective. Res Rep Biochem 5:89-100. CrossRef Medline

Yasui M, Yoshimura T, Takeuchi S, Tokizane K, Tsuda M, Inoue K, Kiyama H (2014) A chronic fatigue syndrome model demonstrates mechanical allodynia and muscular hyperalgesia via spinal microglial activation. Glia 62:1407-1417. CrossRef Medline

Zhang B, Gaiteri C, Bodea LG, Wang Z, McElwee J, Podtelezhnikov AA, Zhang C, Xie T, Tran L, Dobrin R, Fluder E, Clurman B, Melquist S, Narayanan M, Suver C, Shah H, Mahajan M, Gillis T, Mysore J, MacDonald ME, et al. (2013) Integrated systems approach identifies genetic nodes and networks in late-onset Alzheimer's disease. Cell 153:707-720. CrossRef Medline

Zimmermann M (1983) Ethical guidelines for investigations of experimental pain in conscious animals. Pain 16:109-110. CrossRef Medline

Zou W, Reeve JL, Liu Y, Teitelbaum SL, Ross FP (2008) DAP12 couples c-Fms activation to the osteoclast cytoskeleton by recruitment of Syk. Mol Cell 31:422-431. CrossRef Medline 